\title{
The Role of the Anaphylatoxins in Health and Disease
}

\author{
Andreas Klos ${ }^{\mathrm{a}, 1}$, Andrea J. Tenner ${ }^{\mathrm{b}, 1}$, Kay-Ole Johswich ${ }^{\mathrm{a}}$, Rahasson R. Ager ${ }^{\mathrm{b}}$, Edimara S. \\ Reis ${ }^{\mathrm{C}}$, and Jörg Köhlc,d \\ alnstitute of Medical Microbiology and Hospital Epidemiology, Medical School Hannover (MHH), \\ Hannover, Germany \\ bDepartment of Molecular Biology and Biochemistry, Institute for Immunology, Institute for Brain \\ Aging and Dementia, University of California, Irvine, USA \\ CInstitute for Systemic Inflammation Research, University of Lübeck, Lübeck, Germany \\ ${ }^{d}$ Division of Molecular Immunology, Cincinnati Children's Hospital Medical Center and University of \\ Cincinnati College of Medicine, Cincinnati, USA
}

\begin{abstract}
The anaphylatoxins (AT) C3a, C5a and C5a-desArg are generally considered pro-inflammatory polypeptides generated after proteolytic cleavage of $\mathrm{C} 3$ and $\mathrm{C} 5$ in response to complement activation. Their well appreciated effector functions include chemotaxis and activation of granulocytes, mast cells and macrophages. Recent evidence suggests that ATs are also generated locally within tissues by pathogen-, cell-, or contact system-derived proteases. This local generation of ATs is important for their pleiotropic biologic effects beyond inflammation. The ATs exert most of the biologic activities through ligation of three cognate receptors, i.e. the $\mathrm{C} 3 \mathrm{a}$ receptor, the $\mathrm{C} 5 \mathrm{a}$ receptor and the C5a receptor-like, C5L2. Here, we will discuss recent findings suggesting that ATs regulate cell apoptosis, lipid metabolism as well as innate and adaptive immune responses through their impact on antigen-presenting cells and T cells. As we will outline, such regulatory functions of ATs and their receptors play important roles in the pathogenesis of allergy, autoimmunity, neurodegenerative diseases, cancer and infections with intracellular pathogens.
\end{abstract}

\section{Keywords}

Complement; anaphylatoxins; inflammation; sepsis; allergy; Alzheimer disease; adaptive immunity

\section{Introduction}

\begin{abstract}
The complement system is an ancient danger sensing system that recognizes exogenous threats such as conserved microbial motifs as well as endogenous threats including altered-self molecules (e.g. following injury or hypoxia, after virus-infection or tumor-related) and apoptotic cells (Köhl, 2006b). Danger sensing molecules that activate the complement system comprise soluble C-type lectins such as Mannan-binding-lectin (MBL), ficolins, the C-type lectin-like molecule $\mathrm{Clq}$ and, as recent evidence suggests, properdin (Kemper and Hourcade,
\end{abstract}

Corresponding author: Jörg Köhl, MD, Institute for Systemic Inflammation Research, University of Lübeck, Ratzeburger Allee 160, 23538 Lübeck, Germany, Phone number: +49-451-3067; Fax number: +49-451-3069, E-mail address: joerg.koehl@uk-sh.de.

${ }^{1}$ These authors contributed equally to this work

Publisher's Disclaimer: This is a PDF file of an unedited manuscript that has been accepted for publication. As a service to our customers we are providing this early version of the manuscript. The manuscript will undergo copyediting, typesetting, and review of the resulting proof before it is published in its final citable form. Please note that during the production process errors may be discovered which could affect the content, and all legal disclaimers that apply to the journal pertain. 
2008). In addition to this direct recognition of conserved danger motifs, C1q binds strongly to another class of innate danger sensors, i.e. natural immunoglobulins (Ciurana et al., 2004). Once bound to danger motifs, C1q, MBL, ficolins and properdin initiate activation of proteolytic cascades that result in the cleavage of the central molecule of the complement system, C3, followed by cleavage of C5. Together with other cleavage products of C3 (i.e. $\mathrm{C} 3 \mathrm{~b}, \mathrm{iC} 3 \mathrm{~b}, \mathrm{C} 3 \mathrm{dg}, \mathrm{C} 3 \mathrm{~d}$ and $\mathrm{C} 3 \mathrm{c}$ ), the smaller cleavage products of $\mathrm{C} 3$ and $\mathrm{C} 5, \mathrm{C} 3 \mathrm{a}$ and $\mathrm{C} 5 \mathrm{a}$, form a set of soluble mediators that bind distinct cell surface receptors expressed on a variety of target cells. The interaction of $\mathrm{C} 3 \mathrm{a}$ and $\mathrm{C} 5 \mathrm{a}$ with their cognate receptors induces pleiotropic effector functions, translating the danger information from the fluid phase into defined cellular responses. Here, we will review recent findings that provide a better understanding of the mechanisms and pathways underlying the various pro-inflammatory and regulatory functions of the anaphylatoxins (AT) mediated through the three distinct AT receptors.

\section{Anaphylatoxins}

C3a and C5a are small polypeptides consisting of 77 and 74 amino acids, respectively. With $36 \%$ amino acid identity, they share high similarity, but only C5a harbours an N-linked carbohydrate moiety. Furthermore, C5a and C3a are both highly cationic molecules (pI 9.0), the core structure of which is based on a 4-helix bundle that is stabilized by three disulphide bonds (Nettesheim et al., 1988). Interestingly, these features render C3a, but not C5a, a highly potent antimicrobial peptide (Nordahl et al., 2004). Both AT comprise highly conserved Cterminal pentapeptide sequences that are required for activation of their cognate receptors. For C3a, it is LGLAR (Caporale et al., 1980); for C5a, it is MQLGR (Fernandez and Hugli, 1976). Especially for C5a, cyclic C-terminal-derived peptide analogs have been generated such as AcF-(OPdChaWR) that are now in clinical trials for the treatment of several inflammatory diseases (Köhl, 2006a).

The ATs are potent inflammatory mediators targeting a broad spectrum of immune and nonimmune cells. C3a and C5a regulate vasodilation, increase the permeability of small blood vessels, and induce contraction of smooth muscles (Ember et al., 1998). In macrophages (Murakami et al., 1993), neutrophils (Elsner et al., 1994b), and eosinophils (Elsner et al., 1994a) C3a and C5a can trigger oxidative burst. Basophils (Kretzschmar et al., 1993) and mast cells (el Lati et al., 1994) react upon AT stimulation with release of histamine. In eosinophils, $\mathrm{C} 3 \mathrm{a}$ and $\mathrm{C} 5 \mathrm{a}$ regulate the production of eosinophil cationic protein, their adhesion to endothelial cells as well as their migration (Takafuji et al., 1996;DiScipio et al., 1999). C3a further promotes serotonin release from guinea pig platelets (Fukuoka and Hugli, 1988) and modulates synthesis of IL- 6 and TNF- $\alpha$ from B cells and monocytes (Fischer and Hugli, 1997; Fischer et al., 1999). C5a is a powerful chemoattractant for macrophages (Aksamit $e t$ al., 1981), neutrophils (Ehrengruber et al., 1994), activated B (Ottonello et al., 1999) and T cells (Nataf et al., 1999a), basophils (Lett-Brown and Leonard, 1977) and mast cells, the latter of which also migrate towards a C3a gradient (Hartmann et al., 1997).

In addition to their pro-inflammatory properties ATs regulate tissue regeneration (Mastellos et al., 2001; Strey et al., 2003) and tissue fibrosis (Hillebrandt et al., 2005;Addis-Lieser et al., 2005; Strey et al., 2003) as well as brain development (see 4.2) (Benard et al., 2004). Further, C3a has been shown to enhance SDF-1 (CXCL12)-induced homing of hematopoietic stem cells into the bone marrow and their retention in this compartment (Ratajczak et al., 2004).

It is obvious that control mechanisms have evolved that regulate the activity of these powerful bioactive molecules. Indeed, AT activity in the circulation and in tissues is tightly controlled by carboxypeptidases which rapidly cleave off a C-terminal arginine residue (Bokisch and Müller-Eberhard, 1970;Matthews et al., 2004). While the resulting C5a-desArg retains 1-10\% 
of the inflammatory activity of C5a, C3a-desArg is devoid of any pro-inflammatory activity (Sayah et al., 2003).

Intriguingly, C3a-desArg, which is also called acylation stimulating protein (ASP), has been described to possess metabolic hormone activity that drives triglyceride synthesis and glucose uptake in adipose tissue in numerous studies from the Cianflone laboratory (reviewed in (Cianflone et al., 2003)). Surprisingly, ASP concentrations in the range from 1-10 $\mu \mathrm{M}$, which is 2-3 logs above the concentrations usually needed for biological functions of AT, are required for such metabolic activity. In most studies, serum-purified but not recombinant C3a-desArg has been used. C3a-analog C-terminal peptides, which bind and stimulate C3aR, did not cause any changes in lipid metabolism. These findings may point toward a different mode of binding, a different binding partner or may indicate ASP-independent effects, for example induced by co-purified serum proteins. Even more importantly, the in vivo relevance of ASP remains elusive as it still needs to be demonstrated that high micromolar ASP levels can be achieved in adipose tissue. Further, no specific ASP receptor has yet been described on adipocytes (for review see also (Johswich and Klos, 2007)).

\subsection{Anaphylatoxin receptors}

The ATs bind to a family of three receptors, so-called AT receptors, which belong to the superfamily of G-protein-coupled receptors (GPCR). The AT receptor family comprises the $\mathrm{C} 3 \mathrm{a}$ receptor $(\mathrm{C} 3 \mathrm{aR}), \mathrm{C} 5 \mathrm{a}$ receptor $(\mathrm{C} 5 \mathrm{aR})$ and $\mathrm{C} 5 \mathrm{a}$ receptor-like 2 (C5L2). They share high sequence homology (Lee et al., 2001) and are closely related to other chemotactic receptors such as the N-formyl-methionine-leucine-phenylalanine (fMLP) receptor, ChemR23 (Samson et al., 1998) and the chemokine receptors CXCR1 and CXCR2. Despite their similarity, the AT receptors differ in ligand specificity, signal transduction capacity and function.

2.1.1 C3aR - The C3aR specifically binds $\mathrm{C} 3 \mathrm{a}$ with a $\mathrm{K}_{\mathrm{d}}$ of about $1 \mathrm{nM}$, but does not recognize its desarginated form or C5a (Crass et al., 1996;Wilken et al., 1999). It is a $54 \mathrm{kDa}$ molecule comprising 482 amino acids with two glycosylation sites located at asparagines 9 and 195 and a sulfated tyrosine at position 174 (Crass et al., 1999;Ames et al., 1996). Compared to the other AT receptors, $\mathrm{C} 3 \mathrm{aR}$ possesses a remarkable large second extracellular loop that accounts for almost a third of its size and is indispensable for ligand binding. Also, the sulfated tyrosine 174 that resides within this loop plays a pivotal role for the interaction of C3aR with C3a (Gao et al., 2003). However, the receptor N-terminus seems not to be involved in C3a binding (Crass et al., 1999). Upon C3a binding to the C3aR, intracellular signal transduction is promoted via heterotrimeric G-proteins. In neutrophils, C3aR signals through pertussistoxin-sensitive G-proteins (most likely $\mathrm{G}_{\mathrm{i}}$ ) and mobilizes calcium fluxes from the extracellular medium but not from intracellular stores, suggesting that it does not activate phosphatidylinositol-bisphosphate-3-kinase gamma (PI3K- $\gamma$ ) (Norgauer et al., 1993).

However, C3aR may also encounter pertussis-toxin-insensitive $\mathrm{G}_{\alpha 16}$ for signal transduction (Crass et al., 1996). In endothelial cells, C3aR may couple to pertussis-toxin insensitive $\mathrm{G \alpha}_{12}$ or $\mathrm{G \alpha}_{13}$ (Schraufstatter et al., 2002). Downstream signaling events include activation of protein kinase $\mathrm{C}$ by phospholipase $\mathrm{C}$ and, in astrocytes, the mitogen activated protein (MAP) kinases Erk1 and Erk2 (Langkabel et al., 1999;Sayah et al., 2003). Furthermore, in mast cells, $\mathrm{C} 3$ a promotes cytokine expression by signaling pathways that require activation of PI3K and subsequent Akt phosphorylation, as well as MAP kinases Erk1 and Erk2 (Venkatesha et al., 2005).

The $\mathrm{C} 3 \mathrm{aR}$ is expressed on cells of myeloid origin like neutrophils, basophils, eosinophils, mast cells, monocytes/macrophages, dendritic cells (DC) and microglia (Glovsky et al., 1979;Daffern et al., 1995;Klos et al., 1992;Zwirner et al., 1998a;Zwirner et al., 1998b;Gutzmer et al., 2004). Additionally, non-myeloid cells express C3aR. These include astrocytes from 
inflamed brain (Gasque et al., 1998;Ischenko et al., 1998), endothelial cells (Monsinjon et al., 2003), epithelial cells, smooth muscle cells, submucosal and parenchymal vessels of the lung from patients suffering from asthma (Fregonese et al., 2005) and activated but not naive human T cells (Werfel et al., 2000). Other studies have confirmed the absence of C3aR on unstimulated human T cells and on naive or activated human B cells (Zwirner et al., 1999; Martin et al., 1997). More recently, minor C3aR expression has been described on murine $\mathrm{CD}^{+} \mathrm{T}$ cells which was upregulated upon DC stimulation (Strainic et al., 2008). Furthermore, northern blot analysis suggests expression of C3aR mRNA in tissues of lung, liver, kidney, brain, heart, muscle and testis (Hsu et al., 1997).

2.1.2 C5aR-The C5aR (CD88) binds C5a with high affinity $\left(\mathrm{K}_{\mathrm{d}} \sim 1 \mathrm{nM}\right)$ and C5a-desArg with somewhat lower affinity $(\mathrm{KD} \sim 660 \mathrm{nM})$ whereas $\mathrm{C} 3 \mathrm{a}$ and $\mathrm{C} 3 \mathrm{a}$-desArg are not recognized (Gerard and Gerard, 1991;Gerard et al., 1989;Okinaga et al., 2003). C5aR is a $42 \mathrm{kDa}$ protein consisting of 350 amino acids, of which asparagine at position 5 is glycosylated. Additional posttranslational tyrosine sulfation occurs at positions 11 and 14 (Farzan et al., 2001). The essential structures required for ligand binding of C5aR have been elaborated in numerous studies (Mery and Boulay, 1993;DeMartino et al., 1994;Crass et al., 1999;Siciliano et al., 1994;Baranski et al., 1999;Gerber et al., 2000;Geva et al., 2000;Klco et al., 2005;Klco et al., 2006; Matsumoto et al., 2007). The bottom line is that C5a binding involves two distinct sites at the C5aR. First, the aspartate-rich acidic N-terminus of C5aR interacts with the basic core of C5a. Then, the agonistic C-terminus of C5a interacts with a binding pocket formed by hydrophobic residues from the transmembrane domains and charged residues at the base of the extracellular loops. The latter step is indispensable for receptor activation.

C5aR signal transduction depends on heterotrimeric G-proteins. It is mainly achieved by the pertussis toxin sensitive alpha units $\mathrm{G} \alpha_{\mathrm{i} 2}$ (Skokowa et al., 2005) or the pertussis toxin insensitive $\mathrm{G} \alpha_{16}$ (Monk and Partridge, 1993;Amatruda et al., 1993) which is expressed by cells of the hematopoietic lineage. A unique feature of the $\mathrm{C} 5 \mathrm{aR}$ is precoupling to $\mathrm{G}$-proteins in the absence of ligands, thereby apparently lacking a low affinity conformation found in other GPCRs (Siciliano et al., 1990). When C5aR is uncoupled from its G-protein by GTP $\gamma \mathrm{S}$, its affinity is dramatically decreased. In fact, the binding affinity of C5a to the C5aR lacking Gprotein coupling is too low for detection by competitive ligand binding assays (Raffetseder $e t$ al., 1996). C5a binding to C5aR causes calcium fluxes from both, intracellular stores as well as from extracellular medium. After activation, $\beta$-arrestins 1 and 2 bind to C5aR, targeting it for receptor internalization via clathrin coated pits (Braun et al., 2002). Binding of arrestins depends on phosphorylation of the C-terminus of the receptor by G-protein coupled receptor kinases (GRKs). In addition to their function as kinases, GRKs can also interact with other components of intracellular signaling such as Akt, MAPK/ERK kinase (MEK) and PI3K- $\gamma$ (for review see (Ribas et al., 2007)). It has been shown that C5aR activation leads to downstream activation of several components of different signaling pathways like PI3K- $\gamma$ kinase (Perianayagam et al., 2002;la Sala et al., 2005), phospholipase C $\beta 2$ (Jiang et al., 1996), phospholipase D (Mullmann et al., 1990) and Raf-1/B-Raf mediated activation of MEK-1 (Buhl et al., 1994). Another intracellular molecule that binds to the C-terminus of activated C5aR is the Wiskot-Aldrich syndrome protein (WASP) (Tardif et al., 2003). This interaction is significantly increased in the presence of cell division cycle 42 (cdc42), a GTP binding protein which is thought to induce a conformational change of WASP to its active state. WASP is a multifunctional protein that regulates actin dynamics and therefore might play an important role in the C5a dependent chemotaxis.

C5aR is expressed in various cell types. It is most abundantly expressed in neutrophils, eosinophils and basophils, monocytes/macrophages, mast cells and DCs (Chenoweth and Goodman, 1983;Chenoweth and Hugli, 1978;Gerard et al., 1989; Werfel et al., 1997;Morelli et al., 1996). The expression of C5aR in cells of lymphoid origin is not generally accepted. 
Several reports have shown expression in human and mouse T cells (Nataf et al., 1999a;Connelly et al., 2007; Strainic et al., 2008;Lalli et al., 2008). Further, C5a-mediated migration has been demonstrated for B and T cells (El-Naggar et al., 1980). In contrast, in another study binding of C5a has been solely detected in a small subpopulation of $6 \%$ of lymphocytes (Van-Epps and Chenoweth, 1984) and anti-C5aR antibodies failed to demonstrate receptor expression in murine lymphoid cells (Soruri et al., 2003). In addition to immune cells, a body of evidence has accumulated that the $\mathrm{C} 5 \mathrm{aR}$ is expressed in a broad range of non-immune tissue cells (reviewed in (Monk et al., 2007)). These include endothelial cells (Laudes et al., 2002a), neurons (Farkas et al., 1998), astrocytes and microglia (Gasque et al., 1997) as well as cells from kidney, lung, liver, spleen, intestine, skin and heart (Fayyazi et al., 2000;Wetsel, 1995). However, data regarding its expression in epithelial cells of lung, liver and intestine were negatively re-evaluated (Fayyazi et al., 1999;Fayyazi et al., 2000) and found to be misleading due to cross-reactivity of some anti-C5aR antibodies to desmosomal antigens (Werfel et al., 1996).

2.1.3 C5a-receptor-like 2 (C5L2)—C5L2 was discovered in 2000 as putative orphan receptor (GPR77) (Ohno et al., 2000). It is a $37 \mathrm{kDa}$ protein consisting of 337 amino acids with Asparagine 3 as potential glycosylation site. In the conserved transmembrane regions, C5L2 shares 58\% sequence identity with C5aR and 55\% with C3aR (Lee et al., 2001). C5L2 is expressed in various tissues of myeloid and non-myeloid origin and transcripts were detected in brain, placenta, ovary, testis, spleen and colon (Gavrilyuk et al., 2005;Lee et al., 2001). Surface expression of C5L2 was detected in lung, liver, heart, kidney (Gao et al., 2005), in adipose tissue and in skin fibroblasts (Kalant et al., 2005), in neutrophils (Huber-Lang et al., 2005 ) and in immature, but not in mature DCs (Ohno et al., 2000). In combination with a C5aRantagonist, binding of C5a could be demonstrated on differentiated myeloblastic HL-60 and U937 and epithelial HeLa-cells (Johswich et al., 2006). C5L2 and C5aR seem to be frequently co-expressed in most cells or tissues (Okinaga et al., 2003;Gao et al., 2005).

C5a binds with high affinity $\left(\mathrm{K}_{\mathrm{d}}: 2.5 \mathrm{nM}\right)$ to C5L2. Suggesting a slightly different function, C5a-desArg binds with a 20-30 fold higher affinity to C5L2 than to C5aR (Cain and Monk, 2002). Moreover, binding kinetics of the two receptors differ for the same ligand: the on-rate of C5aR is about 100 fold faster than that of C5L2. It is important to consider that only a small percentage of the split products of $\mathrm{C} 5$ and $\mathrm{C} 3$ (close to the nucleus of complement activation) are available as $\mathrm{C} 5 \mathrm{a}$ and $\mathrm{C} 3 \mathrm{a}$ in the circulation as they are rapidly degraded to their desArg products. C5L2 appears to bind C5a and C5a-desArg by different mechanisms. Unlike C5aR, C5L2 uses critical residues in its N-terminal domain for binding only to C5a-desArg (Scola et al., 2007).

In addition to C5a and C5a-desArg binding, C5L2 has been considered a binding partner for C3a, C3a-desArg, C4a and C4a-desArg (Cain and Monk, 2002;Kalant et al., 2003;Okinaga et al., 2003). Re-evaluation of such data revealed "unspecific" binding mainly to plastic surfaces due to the highly cationic nature of the ligands $\mathrm{C} 3 \mathrm{a}$ and $\mathrm{C} 3 \mathrm{a}-\mathrm{des} \mathrm{Arg}$; a binding which mimics in the absence of any cells saturable, specific, high-affinity binding to the C3aR (Johswich et al., 2006). Similar problems had already been reported before with rat mast cells (Kajita and Hugli, 1991). Indeed, using assay conditions that take the cationic nature of the ligands into account, no binding to the recombinant human $\mathrm{C} 5 \mathrm{~L} 2$, at least not in the low or medium nanomolar range, has been observed (Johswich et al., 2006). This does not exclude a biological role for C3a-desArg (ASP) in lipid and glucose metabolism in fat cells and fibroblasts (Kalant et al., 2005). Yet, it makes it highly unlikely that C5L2 is the suggested binding partner for C3a-desArg or C3a.

C5L2 is an enigmatic receptor as a couple of reports suggest opposing functions. On the one hand, it has been described as a non-signaling scavenger receptor for C5a and C5a-desArg. In 
contrast, at least two reports indicate that C5L2 alone, or in conjunction with other receptors, serves as a signaling receptor. In support of a role as a decoy receptor, no mobilization of intracellular $\mathrm{Ca}^{2+}$ occurs in C5L2 transfected cells after AT administration (Cain and Monk, 2002; Okinaga et al., 2003). Moreover, no calcium fluxes have been observed in neutrophils from C5 $\mathrm{aR}^{-/-}$mice after stimulation with C5a (Hopken et al., 1996) or in endogenously, C5L2 expressing cell lines (Johswich et al., 2006). In heptahelical receptors, a highly conserved DRY motif in the third transmembrane domain is important for its interaction with the corresponding G-proteins. The DRY motif is DRF in C5aR and DRC in C3a, but DLC in C5L2. The central arginine residue plays a key role in coordinating the transmembrane domains 3 and 6 and mutagenesis of this residue in C5aR leads to loss of function (Kolakowski, Jr. et al., 1995). When DLC in C5L2 is restored to DRC, C5L2 couples weakly to intracellular $\mathrm{Ca}^{2+}$ fluxes in HEK293 cells co-expressing $\mathrm{G} \alpha_{16}$ (Okinaga et al., 2003). Rat basophilic leukaemia cells (RBL. $2 \mathrm{H} 3$ )-cells are frequently used to study functional intracellular coupling and signaling of AT receptors. Intriguingly, no $\mathrm{Ca}^{2+}$ fluxes occurred in these cells using a C5L2-mutant where the DRY-motif and two additional regions typically involved in G-protein coupling were replaced by the corresponding C5aR-sequences (Scola et al., 2009). Taken together, these findings strongly suggest that C5L2 on its own is uncoupled from G-proteins.

In functional studies, C5L2 failed to promote biologic activities. Preloading of the tyrosine kinase coupled IgE-receptors (Fc\&RI) with DNP-specific IgE resulted in a small increase in $\beta$-hexosaminidase release upon AT pretreatment which was absent in C5L2 transfected RBL cells (Cain and Monk, 2002). Further, C5a binding to C5L2 in bone marrow cells derived from

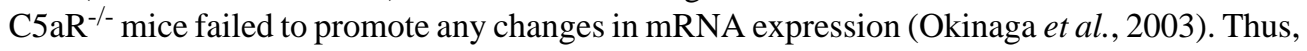
$\mathrm{C} 5 \mathrm{~L} 2$ has been considered to belong to the group of decoy receptors negatively regulating primary inflammatory chemokines (reviewed in (Locati et al., 2005)). Decoy receptors such as US28, CCX CKR, DARC and D6 not only lack the DRY motif and functional coupling, but also constantly recycle giving rise to a high proportion of intracellular receptors combined with highly efficient ligand internalization and degradation.

Rapid ligand-induced receptor internalization is a central feature of functional G-protein coupled receptors. C5aR and C3aR are no exception (Bock et al., 1997; Settmacher et al., 1999). Expressed in RBL.2H3-cells, C5aR rapidly internalizes upon C5a stimulation whereas C5L2 does not (Scola et al., 2009). This view is supported by two independent studies which found no internalization of C5L2 upon stimulation with ATs (Cain and Monk, 2002;Okinaga et al., 2003). On the other hand, C5L2 but not C5aR constitutively recycles in transfected RBL cells leading to major intracellular expression. For example, in transfected $\mathrm{CHO}$ cells $\mathrm{C} 5 \mathrm{~L} 2$ is more efficient than C5aR at internalizing and retaining C5a and C5a-desArg. Additionally, in human neutrophils and HeLa-cells, C5L2 is responsible for internalization and degradation of C5a and C5a-desArg (Scola et al., 2009).

The phosphorylation of C-terminal serine or threonine residues by GRKs, protein kinase A or protein kinase $\mathrm{C}$, followed by their association with arrestins to the receptor is a prerequisite for receptor internalization. C5L2-transfected mouse L1.2 cells elicited only a very basal level of phosphorylation upon C5a stimulation despite a serine/threonine rich C-terminus (Okinaga et al., 2003). In contrast, using transfected HEK293 cells, C5L2 was found to be robustly phosphorylated after stimulation with very high concentrations of C3a-desArg $\left(2 \times 10^{-5} \mathrm{M}\right)$. Further, a cotransfected $\beta$-arrestin-GFP fusion protein translocated from the plasma membrane to endocytic vesicles after stimulation with $\mathrm{C} 5 \mathrm{a}, \mathrm{C} 3 \mathrm{a}$ or $\mathrm{C} 3 \mathrm{a}-\mathrm{desArg}$, thereby suggesting functionality of C5L2 (Kalant et al., 2005). However, this result has recently been questioned, as no translocation of $\beta$-arrestin has been found after C5a-stimulation of transfected RBL.2H3cells (Scola et al., 2009). 
Taken together, there is accumulating evidence that C5L2 is a decoy receptor in primary cells and transfected cell-lines suggesting that it acts as a functional antagonist of the C5aR in vitro and in vivo. Thus biological effects mediated by $\mathrm{C} 5 \mathrm{aR}$ can be expected to be stronger in the absence and weaker in the presence of C5L2. Indeed, neutrophils and macrophages from C5L ${ }^{-/-}$mice produce more TNF- $\alpha$ and IL-6 in response to combined stimulation with C5a and LPS than their wildtype littermates. Further, C5a and LPS stimulation drive more IL-6 production from rat neutrophils when C5L2 is blocked (Gao et al., 2005). In vivo, C5L2-/- mice suffer from augmented inflammatory responses (IL- 6 and TNF- $\alpha$ ) and higher numbers of infiltrating neutrophils when compared to their wildtype littermates in a model of pulmonary immune complex injury (Gerard et al., 2005). The anti-inflammatory role of C5L2 is further supported by a study in which LPS-injected C5L2 $2^{-/-}$mice showed higher IL-1 $\beta$ levels and decreased survival rates (Chen et al., 2007) and a report in which C5L2 $2^{-/-}$mice displayed higher serum concentrations of IL-6 as compared to wildtype and $\mathrm{C}^{2} \mathrm{aR}^{-/-}$mice in a model of septic peritonitis (Rittirsch et al., 2008).

However, under the same conditions, a strong reduction of other inflammatory mediators, such as IL-1 $\beta$, MIP- $1 \alpha$ and MIP-2 was observed in C5L2 $2^{-/-}$mice compared to wildtype mice. Indeed, the concentrations of these mediators were comparable to those of $\mathrm{C}_{5} \mathrm{aR}^{-/-}$mice. Furthermore, $\mathrm{C} 5 \mathrm{~L}^{-/-}$mice, like $\mathrm{C}_{5} \mathrm{aR}^{-/-}$mice, or animals in which each of the receptors was blocked by antibodies, showed a higher survival rate in mid-grade sepsis (Rittirsch et al., 2008). Contrasting the in vitro findings that the C5a/LPS-driven IL-6 production of mouse neutrophils is increased when C5L2 is blocked by antibodies (see above), Chen et al. found decreased IL-6 release from C5L2 ${ }^{-/-}$neutrophils (Chen et al., 2007). Moreover, C5a+LPS-induced Mac-1 surface expression on neutrophils was also diminished. Likewise, whereas C5a or C5a+LPS led to strong ERK1/2- and AKT-phosphorylation in neutrophils from wildtype mice, there was only a weak effect in the absence of C5L2. Additionally, in C5L2 ${ }^{-/-}$macrophages, there was an impaired induction of co-stimulatory molecules (CD40, CD86). Even effects which are mediated by C3a such as ERK1/2- and AKT-phosphorylation or F-actin formation on neutrophils were impaired in C5L2 $2^{-/-}$mice (Chen et al., 2007). In addition to these in vitro findings, inflammatory responses were reduced in vivo in models of thioglycollate induced peritonitis, thioglycollate induced migration into dorsal air pouches, or OVA induced airway hyperresponsiveness. Thus, the studies of Rittirsch et al. and of Chen et al. point to a more complex role of C5L2 in inflammation with C5L2 acting not only as a decoy receptor but also as positive modulator of C5a or even C3a. Although C3a-desArg (ASP) does not bind directly to C5L2 (Johswich et al., 2006), over-expression of C5L2 or its down-regulation by antisense oligonucleotides influenced effects of C3a-desArg (ASP) (Kalant et al., 2005), suggesting that C5L2 can modulate signaling pathways of other receptors. As GPCRs, including C5aR, tend to homo- or hetero-oligomerize (Klco et al., 2003;Rabiet et al., 2008) it is tempting to speculate that such oligomerization may be one mechanism underlying the positive modulatory effect of C5L2 on C5a or C3a effector functions (Rabiet et al., 2008).

\section{Anaphylatoxins in acute and chronic inflammation}

ATs have been shown to promote inflammatory responses during the effector phase of allergic, infectious and autoimmune diseases (reviewed in (Guo and Ward, 2005;Köhl, 2001)). In the following paragraphs, we will focus on recent findings related to the role of C5a in sepsis and the impact of AT receptor signaling on the development of adaptive immune responses in allergy, transplantation, tumor biology and infection.

\subsection{Anaphylatoxins in sepsis}

The sepsis syndrome is still the leading cause of death in intensive care units in the Western world. It is well accepted that invading microorganisms induce the release of a large number of humoral and cellular proinflammatory mediators causing a systemic inflammatory response 
syndrome which defines the patients' outcome. Most microbes activate the complement system through their interaction with $\mathrm{C} 1 \mathrm{q}, \mathrm{MBL} /$ ficolins, or properdin leading to local and/or systemic complement activation with subsequent generation of $\mathrm{C} 3 \mathrm{a}$ and $\mathrm{C} 5 \mathrm{a}$. Indeed, high plasma or serum concentrations of C3a-desArg and C5a-desArg (Bengtson and Heideman, 1988; Weinberg et al., 1984;Hack et al., 1989;Stove et al., 1996;Selberg et al., 2000) have been observed in septic patients and in experimental models of sepsis (Ward, 2008a). Importantly, C3a-desArg plasma levels have been associated with fatal outcome (Hack et al., 1989; Selberg et al., 2000) suggesting a causal role of the ATs in sepsis pathogenesis. The Ward laboratory has contributed tremendously to our understanding of the role of the ATs, and in particular C5a, in experimental sepsis. Most of the work has recently been reviewed (Ward, 2008b;Ward, 2004; Ward, 2008a) and will be summarized only very briefly. Based on the initial observation that interruption of the $\mathrm{C} 5 \mathrm{a} / \mathrm{C} 5 \mathrm{aR}$ interaction in a model of septic peritonitis significantly improved survival (Czermak et al., 1999), several mechanisms have been worked out underlying the detrimental effects of C5a in sepsis. C5a paralyzes immune functions of neutrophils (Huber-Lang et al., 2001), promotes septic cardiomyopathy (Niederbichler $e t$ al., 2006), drives apoptosis of thymocytes (Guo et al., 2000) and adrenal medullary cells (Flierl et al., 2008) and contributes to consumptive coagulopathy (Laudes et al., 2002b). Importantly, $\mathrm{C} 5 \mathrm{aR}$ is markedly upregulated in several organs including lung, liver, kidney, heart as well as in the thymus (Huber-Lang et al., 2002b). Initially, the "dark side of C5a" has been exclusively attributed to the activation of the C5aR. However, assessing the septic peritonitis model in more detail, it turned out that in addition to C5aR, C5L2 is involved in C5a-mediated sepsis. In "mid-grade" sepsis with mortality rates of 60-70\% absence of either C5aR or C5L2 improves survival. In "high-grade" sepsis (mortality rate 100\%) only the combined inhibition of C5aR and C5L2 is protective, suggesting that C5aR and C5L2 synergistically promote septic inflammation (Rittirsch et al., 2008). Importantly, C5L2 but not C5aR was found to regulate the production of the high mobility group box 1 protein (HMBG1) from phagocytes, the ablation of which protects from organ damage and failure in experimental sepsis (Wang $e t$ al., 1999). Further, LPS-induced HMBG-1 production from C5L2-/- macrophages was significantly reduced as compared with WT controls suggesting that C5L2 regulates LPSdriven Toll-like receptor (TLR) 4 activation. Indeed, cross-talk between C5a and TLR signaling has been shown before, although related to C5aR signaling (Hawlisch et al., 2005; Zhang et al., 2007), indicating complex interactions between the complement system and other danger sensing systems (Köhl, 2006b) (see also 3.2.5). In support of this view, MBL and TLR2/6 signaling cooperate in $S$. aureus infection to specify and amplify host defense (Ip et al., 2008).

\subsection{Anaphylatoxins regulate adaptive immune responses}

It is now well appreciated that complement contributes to the regulation of adaptive immune responses (for review see (Carroll, 2004; Köhl, 2006b; Kemper and Atkinson, 2007)). Initially, complement and particularly C3-derived cleavage products have been considered to regulate B cell immunity (Fearon and Locksley, 1996). In a series of elegant studies, it was demonstrated that CD21 (CR2) and CD35 (CR1) are critical for the elimination of self-reactive B cells, selection and and/or maintenance of B1 cells, and the amplitude of humoral responses to thymus-dependent and thymus-independent antigens (summarized in (Carroll, 2004)). During the past 10 years, we have learned that in addition to CD21 and CD35, signaling through other complement receptors including the AT receptors regulates adaptive immune responses. In contrast to CD21 and CD35, AT-mediated regulation focuses on T cell-dependent immune responses promoting inflammation in allergy, autoimmunity, transplantation, tumors and infection with intracellular microorganisms. In the following paragraphs, we will summarize recent findings in these areas. 
3.2.1 Anaphylatoxins in allergic asthma-The worldwide prevalence and severity of allergic asthma in industrialized countries have increased dramatically in recent decades reaching epidemic proportions. In the U.S. alone, 15 million people suffer from this chronic inflammatory disease of the lung. The mechanisms underlying the development of pulmonary allergy in individuals from industrialized countries remain elusive. One important observation is that asthmatics suffer from a dysregulated adaptive immune response which accounts for most of the pathophysiological characteristics found in asthmatics including airflow obstruction, airway hyperresponsiveness (AHR) and airway inflammation. Specifically, environmental factors drive a T helper cell type 2 (Th2)-biased immune response associated with strong production of cytokines such as IL-4, IL-5, and IL-13 which orchestrate the pulmonary inflammatory response, involving the recruitment and the activation of eosinophils, the production of allergen specific IgE, induction of AHR and mucus hypersecretion (WillsKarp, 2004). One of the current challenges is to understand the mechanisms that regulate tolerance towards environmental allergens at the mucosal surface, preventing the development of the maladaptive, Th2-biased immune response in healthy individuals.

ATs are generated in the lungs of both healthy individuals and asthmatics. Under physiologic or steady state conditions, ATs are locally generated in the pulmonary tissue at low levels, while in the inflamed asthmatic environment, high concentrations of ATs are produced (Krug et al., 2001). C3a and C5a play distinct roles in the pathogenesis and the pathology, depending on the conditions under which they are generated and the cell types that become activated.

Under steady state conditions, C5aR signaling at the DC/T cell interface controls the development of the maladaptive immune response towards innocuous aeroallergens (Karp et al., 2000;Köhl et al., 2006;Drouin et al., 2006;McKinley et al., 2006). In an inflamed environment that promotes strong complement activation, C3a (Bautsch et al., 2000; Humbles et al., 2000;Drouin et al., 2002;Drouin et al., 2001;Baelder et al., 2005) as well as C5a (Abe et al., 2001;Baelder et al., 2005;Köhl et al., 2006;Peng et al., 2005) act mainly on infiltrating cells such as eosinophils, mast cells and basophils and promote a proinflammatory scenario. Interestingly, an exclusive role for $\mathrm{C} 3 \mathrm{a}$ has recently been shown in the development of anaphylactic shock in peanut allergy (Khodoun et al., 2009).

The mechanisms underlying the protective role of C5a during allergen sensitization include control of the pulmonary accumulation of immunogenic myeloid DCs, increased release of the Th2 effector cell-homing chemokines CCL17 and CCL22 and the regulation of mDC susceptibility toward the suppressor activity of naturally occurring regulatory T cells (Köhl et al., 2006; Lewkowich et al., 2005). Further insights into the regulatory role of C5 on distinct pulmonary DC population result from a recent study comparing the mechanisms underlying asthma-susceptible $\mathrm{C} 5$-deficient $\mathrm{A} / \mathrm{J}$ mice and resistant $\mathrm{C} 3 \mathrm{H}$ mice. $\mathrm{A} / \mathrm{J}$ mice favor allergen uptake by mDCs leading to upregulation of co-stimulatory molecules and production of a Th2 and Th17-promoting cytokine profile. In contrast, in $\mathrm{C} 3 \mathrm{H}$ mice, allergens are preferentially taken up by tolerogenic plasmacytoid DCs (Lewkowich et al., 2008). These data suggest that C5 and possibly C5a regulate maladaptive immunity in asthma through an impact on pDC. In support of this view, C5aR blockade during allergen sensitization decreases expression of the co-stimulatory molecules B7-H1 (pD-L1) and B7-DC (pD-L2) on pDCs but not on mDCs. Importantly, B7-H1 and B7-DC regulate Th2 cytokine production from $\mathrm{CD} 4^{+} \mathrm{T}$ effector cells (Zhang et al., 2009). Together, these data suggest that C5/C5a sets the threshold for the development of maladaptive immunity by defining the pathways of allergen uptake ( $\mathrm{mDC}$ vs. $\mathrm{pDC}$ ) and the potential of pDCs to suppress mDC-induced activation of T effector cells. In future studies, it will be important to delineate the molecular mechanism by which C5a regulates $\mathrm{mDC}$ and/or $\mathrm{pDC}$ function. At this point, the role of C5L2 in this scenario is unclear. C5L2-deficiency results in a decreased allergic phenotype similar to that seen in C3aRdeficient mice (Chen et al., 2007). 
3.2.2 AT and transplantation-First evidence for an important contribution of local complement production to allograft survival came from the Sacks lab showing that the lack of $\mathrm{C} 3$ in donor kidneys is associated with long-term graft survival in experimental transplantation (Pratt et al., 2002). The association of $\mathrm{C} 3$ polymorphisms with late graft failure confirmed the importance of this finding (Brown et al., 2006) although these data were negatively reevaluated in a larger cohort (Varagunam et al., 2009). Searching for mechanisms contributing to this C3-dependent effect, the same lab found that APCs are the source of $\mathrm{C} 3$ and that macrophages or DCs lacking $\mathrm{C} 3$ have an impaired ability to stimulate alloreactive $\mathrm{T}$ cells and to drive Th1-biased adaptive immune responses (Zhou et al., 2006;Peng et al., 2006). In a follow up study, Peng et al. were able to assign the contribution of $\mathrm{C} 3$ to the interaction of $\mathrm{C} 3 \mathrm{a}$ with the C3aR on DCs. They found that DCs not only synthesize C3 but also harbor the machinery to proteolytically cleave $\mathrm{C} 3$ into $\mathrm{C} 3$ a leading to autocrine $\mathrm{C} 3 \mathrm{aR}$ signaling. Taking advantage of C3aR-deficient DCs, they showed that such cells suffer from reduced MHC-II, co-stimulatory molecule expression and IL-12 production, which was associated with impaired allospecific T cell stimulation (Peng et al., 2008). More recently, C3aR signaling in DCs was shown to decrease cAMP levels as one mechanism by which C3a regulates DC activation and $\mathrm{T}$ cell responses ( $\mathrm{Li}$ et al., 2008). In addition to C3a, C5a might be important in allograft rejection. Inhibition of the $\mathrm{C} 5 \mathrm{aR}$ in murine model of life-supporting renal allotransplantation substantially improved graft survival from $11 \mathrm{~d}$ to 12 weeks. In addition to reduced kidney inflammation and apoptosis, the authors found attenuated priming of alloreactive $\mathrm{T}$ cells (Gueler et al., 2008). In support of these findings, pharmacological targeting of C5aRs during organ preservation was found to improve kidney graft survival (Lewis et al., 2008). Thus, C3aR and $\mathrm{C} 5 \mathrm{aR}$ signaling appear to contribute significantly to the innate and adaptive inflammatory response following solid organ transplantation. Given that several companies have potent C5aR antagonist in their pipeline; more work is required in this area to define the role of AT receptors in allotransplantation in particular with regard to the regulation of $\mathrm{CD} 4^{+}$and $\mathrm{CD} 8^{+} \mathrm{T}$ cell responses and long-term graft survival.

3.2.3 Role of AT receptor signaling in T cell activation-A couple of recent joint publications from the labs of Medof and Heeger suggest that the AT not only act on APCs but also on T cells. In an allogeneic setting or following antigen stimulation, they found that upon APC-T cell interaction, T cells as well as APCs start producing complement factors of the alternative pathway such as factors B and D as well as C3 (Heeger et al., 2005). Further, they demonstrated downregulation of the membrane-bound complement regulator CD55 (decay accelerating factor; DAF). Importantly, DAF-deficient APCs or T cells increased T cell proliferation and Th1 cytokine production in vitro and in vivo. In follow up studies, they were able to link the decreased expression of CD55 on APCs to increased production of C5a which they found to be critical for differentiation into Th1 effector cells (Lalli et al., 2007) confirming the importance of C5a signaling for Th cell differentiation (Hawlisch et al., 2005;Köhl et al., 2006). Extending their studies, they showed that cognate APC-T cell interaction promotes $C 3$ and $\mathrm{C} 5$ production from APCs and T cells and subsequent generation of C3a and C5a. Further, they not only described C3aR and C5aR expression on DCs and naïve, unstimulated CD4 ${ }^{+} \mathrm{T}$ cells but also found upregulation of both AT receptors upon antigen challenge (Strainic et al., 2008). Mechanistically, AT generation and AT receptor upregulation was linked to costimulation by B7-CD28 and CD40-CD40L molecules. Importantly, the authors were able to define autocrine and paracrine feedback loops between AT production, AT receptor and costimulatory molecule expression suggesting that the ATs and their receptors on APCs and $\mathrm{T}$ cells contribute to the network of costimulation required for optimal $\mathrm{T}$ cell activation and differentiation. Further, they showed that naïve T cells already produce low amounts of C3a and C5a under steady state conditions leading to autocrine activation of AT receptors, which seems to promote sustained viability of naïve $\mathrm{T}$ cells. The latter finding was recently extended to effector $\mathrm{T}$ cells. Here they demonstrated that $\mathrm{C} 5 \mathrm{aR}$ signaling on effector $\mathrm{T}$ cells controls 
extrinsic and intrinsic pathways of apoptosis by regulating $\mathrm{T}$ cell expression of the apoptosis regulator proteins Fas and Bcl-2 (Lalli et al., 2008). These data suggest a critical role for complement in the maintenance of naïve T cells and the expansion of effector T cells. Whether this regulatory effect on $\mathrm{T}$ cell differentiation, expansion and apoptosis applies to all subpopulations of $\mathrm{CD}^{+} \mathrm{T}$ cell as well as to $\mathrm{CD}^{+} \mathrm{T}$ cells remains to be determined in future studies.

3.2.4 C5a and cancer-Another example of C5a-mediated regulation of adaptive immunity has recently been uncovered in tumor immunology. The fate of tumors depends on the balance between innate and adaptive immune responses and the potential of the malignant cells to evade immune surveillance. Of particular importance is the interplay between myeloid-derived suppressor cells (MDSC) and $\mathrm{CD}^{+}$cytotoxic T cells. MDSC are a heterogeneous population of regular myeloid cells trapped in intermediate stages of differentiation toward mononuclear cells such as monocytes, macrophages or DCs or polymorphonular granulocytes (Marigo et al., 2008). Markiewski et al. found that MDSC express C5aR and that C5a attracts MDSCs to TC-1 tumor cells in vivo. Further, activation of the C5aR results in increased production of reactive oxygen and nitrogen species from MDSC, which are known mediators of MDSC that suppress $\mathrm{CD}^{+} \mathrm{T}$ cell functions. Importantly, in a model of cervical cancer, genetic or pharmacological C5aR targeting resulted in decreased numbers of MDSCs within the tumor, associated with high numbers of $\mathrm{CD}^{+}$effector $\mathrm{T}$ cells and decreased tumor growth (Markiewski et al., 2008). These data underscore the view of C5a as an important immunoregulatory molecule of adaptive immunity. Of note, C5a may not only be generated in the tumor environment through tumor sensing by C1q-mediated mechanisms. In fact, C5a can be generated from C5 by cell-derived proteases (Huber-Lang et al., 2002a), serine proteases of the clotting and the fibrinolysis system (Huber-Lang et al., 2006;Markiewski and Lambris, 2007) and several pathogens (see 3.2.5) which fits well with the observation that inflammation and infection can promote and enhance tumor growth. In line with this view, C5a cooperates with pathogen-induced TLR activation to drive IL- 6 and IL- $1 \beta$ production from mononuclear cells, which are pro-inflammatory mediators that also increase the accumulation and activation of MDSCs in tumors (Ostrand-Rosenberg, 2008).

\subsubsection{Cross talk of AT receptors with TLRs and its impact on adaptive immune} responses-The complement system and TLRs are ancient danger sensing systems that have co-evolved over hundreds of millions of years. As might have been expected, cross talk between complement proteins and TLRs have been described that suggest rather complex mechanisms of pathogen sensing. Soluble complement proteins such as C1q, MBL/ficolins and properdin (Kemper and Hourcade, 2008) recognize conserved microbial motifs resulting in the activation of the classical, lectin or the alternative pathway of complement. Similarly, conserved microbial patterns are recognized by cellular pattern recognition receptors (PRR) including TLRs. Direct cooperation between the soluble complement-derived sensing molecule MBL and membrane bound TLR 2 has been found in $S$. aureus infection which specifies and amplifies the host response. Importantly, this cooperation takes place in the special environment of the phagosome, suggesting that soluble complement proteins are multifunctional molecules that promote their antimicrobial defense functions not only in the fluid phase but in defined cell compartments (Ip et al., 2008). Another example is the cooperation between TLR2 and CR3 in periodontopathic bacterial infection. Porphyromonas gingivalis exploits the host danger sensing system to shut down adaptive immunity allowing the bacterium to enter host cells and survive within phagosomes. $P$. gingivalis fimbriae are recognized by TLR2 which then stimulates inside-out signaling to promote clustering of CR3, providing a safe and efficient entry pathway for the pathogen. This CR3 activation further leads to suppression of IL-12 production which would otherwise result from TLR2 activation of the phagocyte (Hajishengallis et al., 2008). Interestingly, $P$. gingivalis can degrade C5 to release a C5a-like 
fragment which is biologically active (Wingrove et al., 1992). As C5a can also promote clustering of CR3 (Jones et al., 1998), this may serve as an additional mechanisms of how the microbe exploits host defense. Further, C5a has been shown to cross talk with TLR2, TLR4 and TLR9. In peritoneal macrophages, C5a (and to a lesser extent also C3a) downregulates TLR4-induced production of IL-12 family cytokines including IL-12, IL-27 and IL-23 by PI3K- $\gamma$ and ERK1/2-dependent pathways (Hawlisch et al., 2005). Importantly, this suppressive effect of C5a also applies to CD40-CD40L-induced amplification of IL-12 production in macrophages. The in vivo importance of this effect was demonstrated in a model of cutaneous leishmaniasis. BALB/c mice, which are sensitive to L. major infection, become resistant when C5aR-signaling is ablated in C5aR-deficient mice. This protection is associated with increased proliferation of $\mathrm{CD}^{+}{ }^{+}$and $\mathrm{CD} 8^{+} \mathrm{T}$ cells and high IFN- $\gamma$ production. Of note, L. major uses a similar entry mechanism as $P$. gingivalis, i.e. through CR3 and shuts down IL-12 production upon macrophage infection suggesting that this pathway is an Achilles heel that serves intracellular survival of several pathogens (Liese et al., 2008). In fact activation of CR3 by several ligands has been shown to shut down IL-12 (Marth and Kelsall, 1997). The negative regulatory impact of C5a and C3a on TLR-driven IL-12 production has been confirmed in vivo injecting TLR ligands into mice (Zhang et al., 2007). The bottom line of this study is that the ATs downregulate IL-12 production but act synergistically with TLRs 2, 4 and 9 in promoting TNF- $\alpha$, IL-1 $\beta$, IL-6 and IL-10 production from blood cells.

On the other hand, C5aR blockade has been shown to suppress $S$. aureus-induced production of IL-12 from human monocytes and to enhance the production of IL-10 (Karp et al., 2000) suggesting a synergistic role for C5aR signaling in microbial-derived IL-12 production. Similarly, mice lacking C3aR and C5aR die rapidly following $T$. gondii infection which is associated with a markedly reduced ability to mount protective Th1 immunity (Strainic et al., 2008). Taken together, these data suggest that the impact of C5aR and C $3 \mathrm{aR}$ signaling on microbial-induced production of IL-12 and Th1 protective immunity is complex. The emerging model from the available data is that $\mathrm{C} 5 \mathrm{aR}$ and $\mathrm{C} 3 \mathrm{aR}$ signaling in macrophages and monocytes suppresses TLR-induced IL-12 production. In DCs and T cells, C3aR and C5aR signaling may act synergistically with TLR signaling or activation of other PRR such as NOD-like receptors in case of $S$. aureus infection. More studies are needed that delineate the fascinating cross talk between the distinct AT receptors and PRRs in APCs and T cells in infection in particular with regard to intracellular pathogens.

\subsection{Cross-talk between C5aR and immunoglobulin G receptor (FcyR) in autoimmune diseases}

Autoimmune diseases are chronic disabling disorders in which maladaptive, self-directed immune responses drive severe inflammation. More than 80 autoimmune diseases have been identified, including systemic lupus erythematosus (SLE), multiple sclerosis, type I diabetes and rheumatoid arthritis (RA). Immune complexes (ICs) are integral to the pathogenesis of several autoimmune diseases, including SLE and RA. They activate the classical and the alternative pathway of the complement system and thus interact with both receptors for Fc of immunoglobulin $\mathrm{G}(\mathrm{Fc} \gamma \mathrm{R})$ and a variety of complement receptors (Köhl, 2001). When clearance mechanisms are overwhelmed, ICs can become an important cause of tissue damage. In such settings, ICs promote proinflammatory processes characterized by activation of myeloid cells at sites of IC deposition.

In mice, four different Fc $\gamma$ Rs have been described, the activating Fc $\gamma$ Rs I, III and IV and the inhibitory Fc $\gamma$ RIIB (Nimmerjahn and Ravetch, 2006). IC binding to activating Fc $\gamma$ Rs promotes inflammation through an immunoreceptor tyrosine-based activation motif (ITAM) whereas ligation of the inhibitory Fc $\gamma$ RIIB blocks the inflammatory response upon co-ligation with activating Fc $\gamma$ Rs through an immunoreceptor tyrosine-based inhibitory motif (ITIM). This 
coupling of activating and inhibitory signals from cellular receptors which recognize similar ligands has emerged as a general principle during evolution in which the overall response is determined by the relative contribution of each signaling pathway (Ravetch and Lanier, 2000). In line with this view, Fc $\gamma$ RIIB deficient mice suffer from augmented inflammation in experimental models of IC-disease, systemic anaphylaxis, and show enhanced IgG-mediated clearance of pathogens and tumor cells (Takai, 2002).

Several studies of experimental IC-disease have shown that both activating Fc $\gamma$ Rs (Sylvestre and Ravetch, 1994), as well as the C5aR (CD88) (Heller et al., 1999a;Heller et al., 1999b;Baumann et al., 2000;Baumann et al., 2001), drive effector responses in IC-mediated inflammation and that cross-regulation exists between the two receptor signaling pathways (Shushakova et al., 2002; Godau et al., 2004). The emerging paradigm is that activating Fc $\gamma \mathrm{Rs}$ provide IC-mediated cellular effector responses, while C5a sets the threshold for Fc $\gamma \mathrm{R}$ activation by upregulation of activating Fc $\gamma$ Rs and downregulation of Fc $\gamma$ RIIB. C5aR signaling through $\mathrm{G}_{\alpha \mathrm{i} 2}$-dependent mechanisms (Skokowa et al., 2005) that activate PI3K- $\gamma$ and $\delta$ (Konrad et al., 2008) are critical for the regulatory impact of C5a on Fc $\gamma \mathrm{R}$ expression. Indeed, contribution of both Fc $\gamma R$ s and C5aR has been shown in models of IC-alveolitis and peritonitis (Baumann et al., 2000; Heller et al., 1999a), rheumatoid arthritis (Ji et al., 2002), autoimmune vitiligo (Trcka et al., 2002), and autoimmune hemolytic anemia (AIHA) (Kumar et al., 2006). Further, a positive amplification loop has been described between Fc $\gamma \mathrm{R}$ signaling and the complement system in a model of AIHA in which activating Fc $\gamma$ Rs promote the production of C5 from tissue macrophages for its subsequent cleavage into C5a (Kumar et al., 2006).

Taken together, these data suggest that the interplay between Fc $\gamma$ Rs and C5aR contributes significantly to the effector phase of IC diseases, i.e. the enhancement of Fc $\gamma \mathrm{R}$-mediated clearance of ICs by macrophages and the pro-inflammatory scenario through the recruitment and activation of neutrophils. Given that Fc $\gamma$ Rs, in particular Fc $\gamma$ RIIB, contributes to the development of autoimmunity (Takai, 2002), it will be important to delineate in future studies whether the regulatory link between C5aR and Fc $\gamma$ RIIB will also affect afferent immunity and the development of autoimmune diseases such as SLE.

\section{Anaphylatoxins and their receptors in CNS}

\subsection{Evidence for a role for $\mathrm{C5a} / \mathrm{C} 5 \mathrm{aR}$ in Neurodegenerative disease}

Degenerative diseases are becoming a larger issue in the modern age in which lifespan has been prolonged. One example of age related neurodegenerative disorders is Alzheimer's Disease (AD) with over 4.5 million individuals in the US alone afflicted with the disease, most above the age of 65 (Hebert et al., 2003). Symptoms of the disease include: loss of memory, decreased reasoning and communication ability and loss of independence. The characteristic neuropathological changes include synaptic and neuronal loss, extracellular amyloid beta $(\mathrm{A} \beta)$ plaques and neurofibrillary tangles of hyperphosphorylated tau mainly within the hippocampus and cortex of the brain (Terry et al., 1999;Trojanowski and Lee, 2005;Aizenstein et al., 2008). The observation that individuals who take non-steroidal anti-inflammatory drugs (NSAIDs) show decreased susceptibility to AD onset (Pasinetti, 2002), as well as a plethora of in vitro data (Bales et al., 2000;Shaftel et al., 2008;Meda et al., 2001;Veerhuis et al., 2003), have led many to speculate that inflammation may play a substantial role in AD pathogenesis. In contrast to diffuse plaques seen in brain tissue from non-demented individuals, the $\mathrm{A} \beta$ peptide in plaques in $\mathrm{AD}$ brain is in a $\beta$-sheet structure conformation (can be stained with a dye thioflavine) and has been termed fibrillar in contrast to diffuse. Components of the complement system have been observed almost exclusively in association with these fibrillar A $\beta$ plaques (Afagh et al., 1996;Loeffler et al., 2008). Some positive complement immunostaining has been shown in thioflavine-negative, cognitively normal brains, but to a far lesser extent (Lue et al., 2001). In vitro studies have shown that these $\beta$-sheet rich A $\beta$ 
assemblies activate both the classical and alternative complement pathways (Rogers et al., 1992;Jiang et al., 1994;Bradt et al., 1998;Watson et al., 1997), thus generating complement activation products, including $\mathrm{C} 3 \mathrm{~b}, \mathrm{C} 3 \mathrm{a}$ and $\mathrm{C} 5 \mathrm{a}$. Prolonged complement activation triggered by fibrillar $\mathrm{A} \beta$ plaques or activation in the absence of proper regulation may contribute to many of the manifestations present in the disease (Cotman et al., 1996) due to C5a-recruited and activated glia that promote inflammatory events (Akiyama et al., 2000;Grammas and Ovase, 2001; Yao et al., 1990;O'Barr and Cooper, 2000). Furthermore, studies have suggested that C5aR activation may be involved in neuronal apoptosis (Farkas et al., 2003) and decreased cell viability (Humayun et al., 2009). Similar scenarios may apply to Parkinson disease (McGeer and McGeer, 2004), Huntington's disease (Singhrao et al., 1999) and age relate macular degeneration (AMD) (Hageman et al., 2005). For example, complement components, glia and complement AT receptor mRNAs are strongly expressed in caudate in Huntington's disease. Complement components are found in drusen in AMD, and over $70 \%$ of the risk of AMD can be attributed to polymorphisms predominantly in the endogenous complement pathway regulator, Factor $\mathrm{H}$, with some contributions from polymorphisms in $\mathrm{C} 2, \mathrm{C} 3$, and Factor B (Maller et al., 2007;Jakobsdottir et al., 2008;Spencer et al., 2008;Spencer et al., 2007). Complement activation is strongly implicated in cerebral ischemia and hemorrhagic stroke, although the precise contributions and mechanisms of complement-dependent neuronal degeneration are yet to be unequivocally defined. The evidence for, and consequences of, C3a and C5a generated as a result of this injury has recently been thoroughly reviewed by Arumugan and colleagues and thus will not be discussed here further (Arumugam et al., 2009).

The role of the complement system in neurodegenerative disease progression appears to be a complex one, with evidence demonstrating both complement-dependent detrimental effects and protective effects. Indeed, C3a and C5a are generated during many/most pathological events in the CNS (Bonifati and Kishore, 2007). A vital tool in exploring the possible mechanisms and overall contribution of complement initiated pathogenesis has been the use of animal models of disease. Murine models are particularly important as mice genetically deficient in specific complement components such as C1q, C3, C5, and Factor B are available for use in dissecting the role of complement in general and/or the function of the individual component. In addition, novel approaches such as "ectopic" expression of C3a or C5a may also prove useful in validating the direct role of these mediators in disease (Boos et al., 2004). Since it has been demonstrated that receptors for C5a are expressed in the brain (Gasque et al., 1997;Gasque et al., 1998;Singhrao et al., 1999;O'Barr et al., 2001;Nataf et al., 1999b) and that CNS cells do respond to C5a (Sayah et al., 2003), the complement activation product $\mathrm{C} 5 \mathrm{a}$ has been the focus of several recent CNS studies. For example, a lack of C5/C5a rendered mice resistant to cerebral malaria (Patel et al., 2008), and significantly reduced neutrophil recruitment and CNS damage in a traumatic brain injury model (Sewell et al., 2004), supporting the hypothesis that C5a can exacerbate inflammation in the CNS, with involvement of either mononuclear phagocytes or infiltrating neutrophils. Interestingly, C3a but not C5a, had a dominant effect in accelerating experimental autoimmune encephalomyelitis (EAE) (Boos et al., 2004).

Mouse models expressing human mutated forms of the amyloid precursor protein (APP) have been shown to develop age-related accumulation of $A \beta$ in the brain, and have been reported to mimic certain other features associated with human age-related AD pathology, including the association of complement components, such as C1q, C3 and C4 (Fonseca et al., 2004;Zhou et al., 2005;Zhou et al., 2008), as well as reactive/inflammatory astrocytes and microglia, with the fibrillar $\mathrm{A} \beta$ plaques. Treatment of one $\mathrm{AD}$ mouse model $\left(\mathrm{APP}_{23}\right)$ with a low molecular weight heparin, enoxaparin, which is an inhibitor of $A \beta$ mediated classical complement activation reduced $A \beta$ load and astrocyte activation (Bergamaschini et al., 2004), thus suggesting complement inhibition may result in reduced $\mathrm{AD}$ associated pathology. Further and more direct evidence for complement involvement in $\mathrm{AD}$ pathogenesis was demonstrated by 
crossing an AD mouse model (Tg2576) to a C1q knock out to generate an AD mouse lacking the ability to activate the classical complement pathway. These C1q-deficient mice had significant reductions in glial activation as well as increased neuronal integrity in contrast to C1q-sufficient Tg2576 mice (Fonseca et al., 2004). Interestingly, however, the genetic deficiency of $\mathrm{C} 5$ has been shown to be one of a limited number of genetic differences that are associated with decreased amyloid deposition in DBA/2J mice vs. C57B16 mice transgenic for the human APP gene (Ryman et al., 2008). As is the case for peripheral monocytes, C5a has been shown to be chemotactic for microglia and astrocytes (Miller and Stella, 2008; Yao et al., 1990), and thus in $\mathrm{AD}$ may provide a significant signal for glial recruitment to the plaque vicinity. In addition, C5a can synergize with other ligands to induce proinflammatory cytokine and/or chemokine production (O'Barr and Cooper, 2000), and thus can contribute to a secondary/synergistic inflammatory reaction to the plaques, particularly since fibrillar amyloid may bind TLR2 and TLR4 (Jana et al., 2008;Lotz et al., 2005) and TLR and C5aR have been shown to synergize in other tissues (Zhang et al., 2007;Hawlisch and Köhl, 2006). This exacerbated inflammatory nidus likely contributes to neurotoxicity and the subsequent cognitive loss symptomatic of AD.

Since many of the detrimental effects of complement can result from the influx and activation of inflammatory myeloid-derived cells (neutrophils, macrophages, microglia) or synergistic signaling with other receptors, such as P2Y6 (Flaherty et al., 2008) or TLRs (Zhang et al., 2007; Hawlisch et al., 2005), developing inhibitors of C5a activation of myeloid cells and/or receptor antagonists of C5a has been targeted as major mechanism for inhibiting acute C5ainduced inflammatory disorders as well as chronic debilitating disorders (Konteatis et al., 1994). The C5a receptor antagonist PMX-205, a derivative of PMX-53 (Köhl, 2006a), which is an orally active CD88-specific receptor antagonist, has been shown to reduce disease activity in several animal models, including models of CNS disease such as brain trauma (Sewell $e t$ al., 2004), Amyotrophic Lateral Sclerosis (ALS) (Woodruff et al., 2008) and Huntington-like neurodegeneration (Woodruff et al., 2006). Mouse models of AD, treated with PMX-205, have also shown significant decreases in both fibrillar $A \beta$ and inflammatory glia in cortex and hippocampus (Fonseca, Ager, et al., submitted). These reductions in pathology were correlated with improvements in cognitive performance. These observations provide experimental evidence for a role for $\mathrm{C} 5 \mathrm{aR} / \mathrm{CD} 88$ in neurodegenerative disease progression. In addition, the results suggest that blockade of a receptor for complement-mediated inflammation reduces neuroinflammation and behavioral deficits, and may serve as a potent therapeutic target for those afflicted with $\mathrm{AD}$ and other neurodegenerative diseases that are accelerated by complement mediated inflammation.

\subsection{Neurogenesis and Development}

Interestingly, seemingly contradictory results were reported in other studies of the influence of the complement component $\mathrm{C} 5$ on inflammation. C5a, when given with kainic acid intraventricularly or 24 hours prior to glutamate treatment in neuronal mouse cultures, was shown to be neuroprotective against glutamate mediated caspase-3 activation (Osaka et al., 1999). It was subsequently hypothesized that the C5a mediated protection may be dependent on the modulation of $\mathrm{Ca}^{2+}$ and MAP-kinase activity (Mukherjee and Pasinetti, 2000; Mukherjee and Pasinetti, 2001). In other systems, C5a, as well as C3a, provided direct neuroprotection (Van Beek et al., 2001;Mukherjee and Pasinetti, 2001;O'Barr and Cooper, 2000); however, these were cell lines and/or neurons perhaps at different stages of maturation which may align with the studies of Fontaine and colleagues in newborn rat brain. These researchers demonstrate that in the developing cerebellar cortex brain, C5aR stimulation triggered increased BrdU incorporation by granule neurons and a $\mathrm{C} 3 \mathrm{aR}$ agonist promoted migration of cells to their proper location (Jauneau et al., 2006;Benard et al., 2004;Benard et al., 2008). However, since defects in cerebellum have not been reported in $\mathrm{C} 3, \mathrm{C} 3 \mathrm{aR}, \mathrm{C} 5$ or $\mathrm{C} 5 \mathrm{aR}$ deficient animals, 
further studies will be necessary to determine if these systems are redundant, residual or involved in facilitating survival and development during infection. The underlying basis for the differences in outcome due to $\mathrm{C} 5 \mathrm{a} / \mathrm{C} 3 \mathrm{a}$ engagement of their receptors are likely different differentiation states of the cells and/or the cell signaling resulting from mixed cell interaction. Another example of the complexity of these responses is the report that C5a (but not C3a) drives up expression of microglial (but not astrocyte) glutamate receptor (GLT-1) which should provide increased glutamate uptake and thus protect neurons in the environment against glutamate toxicity (Humayun et al., 2009). Since the two C5aR (CD88 and C5L2) may "cooperate" with other receptors (see 3.2.5 and 3.3), it is possible that a diverse, but precise set of responses to a changing environment could be orchestrated depending on the repertoire of interacting receptors available in the sensing cell. Clearly a "systems" approach to these responses will facilitate the clarification of these pathways and identification of targets for therapeutic interventions.

The ATs have been shown to be important for both hepatocyte proliferation and regeneration (Reca et al., 2003;Daveau et al., 2004;Mastellos et al., 2001;Markiewski et al., 2004). Recent reports in addition to those mentioned above involving development of rat cerebellum, have implicated $\mathrm{C} 3 \mathrm{a}$ (and possibly $\mathrm{C} 5 \mathrm{a}$ ) in neural stem cell regeneration and directed migration of stem cells. After demonstrating that both clonally derived rat hippocampal neural stem cells and murine neural progenitor cells expressed receptors for $\mathrm{C} 3 \mathrm{a}$ and $\mathrm{C} 5 \mathrm{a}$, mice lacking $\mathrm{C} 3$, $\mathrm{C} 3 \mathrm{aR}$, or had C3aR activity inhibited with an antagonist, showed reductions in migrating neuroblasts and newly formed neurons in areas of basal adult neurogenesis (Rahpeymai et al., 2006). A similar reduction in neuroblast migration and number of newly formed neurons was observed after ischemic injury in the deficient or C3aR-inhibited mice. Although their study did not provide a mechanism behind the $\mathrm{C} 3$ a receptor activation that would lead to the creation of new neurons nor a source for the generation of $\mathrm{C} 3 \mathrm{a}$ or $\mathrm{C} 5 \mathrm{a}$ (their results did not rule out a contribution of $\mathrm{C} 5 \mathrm{a}$ ), their results do provide evidence that complement components can play a role in neurogenesis. Interestingly, it has been reported that $\mathrm{C} 3 \mathrm{a}$ induces or synergizes with IL-1 $\beta$ to enhance NGF expression (Heese et al., 1998;Jauneau et al., 2006) in human microglial cell cultures, which implicates the possible involvement/cross talk between these two systems. Taken together, it will be important to try to preserve and/or enhance the potential protective/reparative effects of specific ATs in the CNS when designing therapeutic targets.

\section{Conclusions}

Since the discovery of the ATs almost 40 years ago and their respective receptors 10-15 years ago, our view of the ATs as mere pro-inflammatory mediators generated in response to complement activation has changed. Today we consider ATs as immunoregulatory molecules with pleiotropic biologic functions, the development of which can be complement systemdependent or independent through serine proteases of different origins. Except the ancient antimicrobial activity and the metabolic activity of $\mathrm{C} 3 \mathrm{a} / \mathrm{C} 3 \mathrm{ades} \mathrm{Arg}$, ATs exert their biologic activities through ligation of their cognate receptors, belonging to the most abundant receptor family in vertebrates, i.e. the GPCRs. Depending on the local environment and the circumstances under which ATs are generated, they can contribute to cell and tissue homeostasis, the benefit or burden of inflammation as well as to tissue regeneration or fibrosis. Based on the strong pro-inflammatory properties, C5a and the C5aR in particular have been considered attractive pharmacological targets. Several companies have C5aR antagonists in their pipelines to attenuate inflammation in allergic asthma, ischemia/reperfusion injury, rheumatoid arthritis or age-related macular degeneration. While C5aR targeting appears an attractive approach in acute inflammation, long term approaches should consider direct or indirect effects of AT receptor signaling on adaptive immune responses, cell apoptosis and tissue regeneration/fibrosis that may impact on such treatments. 


\section{Acknowledgments}

The authors thank the following institutions for providing support for the work cited in this review: National Institute of Allergy and Infectious Diseases (NIAID) grants AI059305 and AI057839 to J.K. NS-35144 (AJT), P50 - AG 00538 (AJT), NIH Training Grant NS-007444 (RRA). DFG grant of the SFB 566 (A.K.) The Ministry of Science and Culture of Lower Saxony through a Georg-Christoph-Lichtenberg Scholarship (K-O. J.) We thank Una Doherty for proofreading and excellent assistance in the preparation of the manuscript.

\section{References}

1. Abe M, Shibata K, Akatsu H, Shimizu N, Sakata N, Katsuragi T, Okada H. Contribution of anaphylatoxin $\mathrm{C} 5 \mathrm{a}$ to late airway responses after repeated exposure of antigen to allergic rats. $\mathrm{J}$ Immunol 2001;167:4651-4660. [PubMed: 11591795]

2. Addis-Lieser E, Köhl J, Chiaramonte MG. Opposing regulatory roles of complement factor 5 in the development of bleomycin-induced pulmonary fibrosis. J Immunol 2005;175:1894-1902. [PubMed: 16034133]

3. Afagh A, Cummings BJ, Cribbs DH, Cotman CW, Tenner AJ. Localization and cell association of C1q in Alzheimer's disease brain. Exp Neurol 1996;138:22-32. [PubMed: 8593893]

4. Aizenstein HJ, Nebes RD, Saxton JA, Price JC, Mathis CA, Tsopelas ND, Ziolko SK, James JA, Snitz BE, Houck PR, Bi W, Cohen AD, Lopresti BJ, DeKosky ST, Halligan EM, Klunk WE. Frequent amyloid deposition without significant cognitive impairment among the elderly. Arch Neurol 2008;65:1509-1517. [PubMed: 19001171]

5. Akiyama H, Arai T, Kondo H, Tanno E, Haga C, Ikeda K. Cell mediators of inflammation in the Alzheimer disease brain. Alzheimer Dis Assoc Disord 2000;14:S47-S53. [PubMed: 10850730]

6. Aksamit RR, Falk W, Leonard EJ. Chemotaxis by mouse macrophage cell lines. J Immunol 1981;126:2194-2199. [PubMed: 7229371]

7. Amatruda TT, Gerard NP, Gerard C, Simon MI. Specific interactions of chemoattractant factor receptors with G- proteins. J Biol Chem 1993;268:10139-10144. [PubMed: 8486684]

8. Ames RS, Li Y, Sarau HM, Nuthulaganti P, Foley JJ, Ellis C, Zeng Z, Su K, Jurewicz AJ, Hertzberg RP, Bergsma DJ, Kumar C. Molecular cloning and characterization of the human anaphylatoxin C3a receptor. J Biol Chem 1996;271:20231-20234. [PubMed: 8702752]

9. Arumugam TV, Woodruff TM, Lathia JD, Selvaraj PK, Mattson MP, Taylor SM. Neuroprotection in stroke by complement inhibition and immunoglobulin therapy. Neuroscience 2009;158:1074-1089. [PubMed: 18691639]

10. Baelder R, Fuchs B, Bautsch W, Zwirner J, Köhl J, Hoymann HG, Glaab T, Erpenbeck V, Krug N, Braun A. Pharmacological targeting of anaphylatoxin receptors during the effector phase of allergic asthma suppresses airway hyperresponsiveness and airway inflammation. J Immunol 2005;174:783789. [PubMed: 15634899]

11. Bales KR, Du Y, Holtzman D, Cordell B, Paul SM. Neuroinflammation and Alzheimer's disease: critical roles for cytokine/Abeta-induced glial activation, NF-kappaB, and apolipoprotein E. Neurobiol Aging 2000;21:427-432. [PubMed: 10858588]

12. Baranski TJ, Herzmark P, Lichtarge O, Gerber BO, Trueheart J, Meng EC, Iiri T, Sheikh SP, Bourne HR. C5a receptor activation Genetic identification of critical residues in four transmembrane helices. J Biol Chem 1999;274:15757-15765. [PubMed: 10336477]

13. Baumann U, Chouchakova N, Gewecke B, Köhl J, Carroll MC, Schmidt RE, Gessner JE. Distinct tissue site-specific requirements of mast cells and complement components $\mathrm{C} 3 / \mathrm{C} 5 \mathrm{a}$ receptor in $\mathrm{IgG}$ immune complex-induced injury of skin and lung. J Immunol 2001;167:1022-1027. [PubMed: 11441111]

14. Baumann U, Köhl J, Tschernig T, Schwerter-Strumpf K, Verbeek JS, Schmidt RE, Gessner JE. A codominant role of $\mathrm{Fc}$ gamma RI/III and C5aR in the reverse Arthus reaction. J Immunol 2000;164:1065-1070. [PubMed: 10623857]

15. Bautsch W, Hoymann HG, Zhang Q, Meier-Wiedenbach I, Raschke U, Ames RS, Sohns B, Flemme N, Meyer z V, Grove M, Klos A, Köhl J. Cutting edge: guinea pigs with a natural C3a-receptor defect exhibit decreased bronchoconstriction in allergic airway disease: evidence for an involvement of the 
C3a anaphylatoxin in the pathogenesis of asthma. J Immunol 2000;165:5401-5405. [PubMed: 11067890]

16. Benard M, Gonzalez BJ, Schouft MT, Falluel-Morel A, Vaudry D, Chan P, Vaudry H, Fontaine M. Characterization of $\mathrm{C} 3 \mathrm{a}$ and $\mathrm{C} 5 \mathrm{a}$ receptors in rat cerebellar granule neurons during maturation Neuroprotective effect of C5a against apoptotic cell death. J Biol Chem 2004;279:43487-43496. [PubMed: 15292245]

17. Benard M, Raoult E, Vaudry D, Leprince J, Falluel-Morel A, Gonzalez BJ, Galas L, Vaudry H, Fontaine M. Role of complement anaphylatoxin receptors (C3aR, C5aR) in the development of the rat cerebellum 140. Mol Immunol 2008;45:3767-3774. [PubMed: 18635264]

18. Bengtson A, Heideman M. Anaphylatoxin formation in sepsis. Arch Surg 1988;123:645-649. [PubMed: 3282496]

19. Bergamaschini L, Rossi E, Storini C, Pizzimenti S, Distaso M, Perego C, De Luigi A, Vergani C, Grazia DS. Peripheral treatment with enoxaparin, a low molecular weight heparin, reduces plaques and beta-amyloid accumulation in a mouse model of Alzheimer's disease. J Neurosci 2004;24:41814186. [PubMed: 15115813]

20. Bock D, Martin U, Gartner S, Rheinheimer C, Raffetseder U, Arseniev L, Barker MD, Monk PN, Bautsch W, Köhl J, Klos A. The C terminus of the human C5a receptor (CD88) is required for normal ligand-dependent receptor internalization. Eur J Immunol 1997;27:1522-1529. [PubMed: 9209506]

21. Bokisch VA, Müller-Eberhard HJ. Anaphylatoxin inactivator of human plasma: its isolation and characterization as a carboxypeptidase. J Clin Invest 1970;49:2427-2436. [PubMed: 4098172]

22. Bonifati DM, Kishore U. Role of complement in neurodegeneration and neuroinflammation. Mol Immunol 2007;44:999-1010. [PubMed: 16698083]

23. Boos L, Campbell IL, Ames R, Wetsel RA, Barnum SR. Deletion of the complement anaphylatoxin $\mathrm{C} 3 \mathrm{a}$ receptor attenuates, whereas ectopic expression of $\mathrm{C} 3 \mathrm{a}$ in the brain exacerbates, experimental autoimmune encephalomyelitis. J Immunol 2004;173:4708-4714. [PubMed: 15383607]

24. Bradt BM, Kolb WP, Cooper NR. Complement-dependent proinflammatory properties of the Alzheimer's disease beta-peptide. J Exp Med 1998;188:431-438. [PubMed: 9687521]

25. Braun L, Christophe T, Boulay F. Phosphorylation of key serine residues is required for internalization of the C5a anaphylatoxin receptor via a beta -arrestin, dynamin and clathrin-dependent pathway. $\mathrm{J}$ Biol Chem 2002;278:4277-4285. [PubMed: 12464600]

26. Brown KM, Kondeatis E, Vaughan RW, Kon SP, Farmer CK, Taylor JD, He X, Johnston A, Horsfield C, Janssen BJ, Gros P, Zhou W, Sacks SH, Sheerin NS. Influence of donor C3 allotype on late renaltransplantation outcome. N Engl J Med 2006;354:2014-2023. [PubMed: 16687714]

27. Buhl AM, Avdi N, Worthen GS, Johnson GL. Mapping of the C5a receptor signal transduction network in human neutrophils. Proc Natl Acad Sci U S A 1994;91:9190-9194. [PubMed: 8090790]

28. Cain SA, Monk PN. The orphan receptor C5L2 has high affinity binding sites for complement fragments C5a and C5a des-Arg(74). J Biol Chem 2002;277:7165-7169. [PubMed: 11773063]

29. Caporale LH, Tippett PS, Erickson BW, Hugli TE. The active site of C3a anaphylatoxin. J Biol Chem 1980;255:10758-10763. [PubMed: 6968751]

30. Carroll MC. The complement system in regulation of adaptive immunity. Nat Immunol 2004;5:981986. [PubMed: 15454921]

31. Chen NJ, Mirtsos C, Suh D, Lu YC, Lin WJ, McKerlie C, Lee T, Baribault H, Tian H, Yeh WC. C5L2 is critical for the biological activities of the anaphylatoxins C5a and C3a. Nature 2007;446:203207. [PubMed: 17322907]

32. Chenoweth DE, Goodman MG. The C5a receptor of neutrophils and macrophages. Agents Actions Suppl 1983;12:252-273. [PubMed: 6573117]

33. Chenoweth DE, Hugli TE. Demonstration of specific C5a receptor on intact human polymorphonuclear leukocytes. Proc Natl Acad Sci U S A 1978;75:3943-3947. [PubMed: 279010]

34. Cianflone K, Xia Z, Chen LY. Critical review of acylation-stimulating protein physiology in humans and rodents. Biochim Biophys Acta 2003;1609:127-143. [PubMed: 12543373]

35. Ciurana CL, Zwart B, van M G, Hack CE. Complement activation by necrotic cells in normal plasma environment compares to that by late apoptotic cells and involves predominantly IgM. Eur J Immunol 2004;34:2609-2619. [PubMed: 15307193] 
36. Connelly MA, Moulton RA, Smith AK, Lindsey DR, Sinha M, Wetsel RA, Jagannath C. Mycobacteria-primed macrophages and dendritic cells induce an upregulation of complement C5a anaphylatoxin receptor (CD88) in CD3+ murine T cells. J Leukoc Biol 2007;81:212-220. [PubMed: 16997854]

37. Cotman CW, Tenner AJ, Cummings BJ. $\beta$-Amyloid converts an acute phase injury response to chronic injury responses. Neurobiol Aging 1996;17:723-731. [PubMed: 8892345]

38. Crass T, Ames RS, Sarau HM, Tornetta MA, Foley JJ, Köhl J, Klos A, Bautsch W. Chimeric receptors of the human C3a receptor and C5a receptor (CD88). J Biol Chem 1999;274:8367-8370. [PubMed: 10085065]

39. Crass T, Raffetseder U, Martin U, Grove M, Klos A, Köhl J, Bautsch W. Expression cloning of the human C3a anaphylatoxin receptor (C3aR) from differentiated U-937 cells. Eur J Immunol 1996;26:1944-1950. [PubMed: 8765043]

40. Czermak BJ, Sarma V, Pierson CL, Warner RL, Huber-Lang M, Bless NM, Schmal H, Friedl HP, Ward PA. Protective effects of C5a blockade in sepsis. Nat Med 1999;5:788-792. [PubMed: 10395324]

41. Daffern PJ, Pfeifer PH, Ember JA, Hugli TE. C3a is a chemotaxin for human eosinophils but not for neutrophils. I. C3a stimulation of neutrophils is secondary to eosinophil activation. J Exp Med 1995;181:2119-2127. [PubMed: 7760001]

42. Daveau M, Benard M, Scotte M, Schouft MT, Hiron M, Francois A, Salier JP, Fontaine M. Expression of a functional C5a receptor in regenerating hepatocytes and its involvement in a proliferative signaling pathway in rat. J Immunol 2004;173:3418-3424. [PubMed: 15322206]

43. DeMartino JA, Van Riper G, Siciliano SJ, Molineaux CJ, Konteatis ZD, Rosen H, Springer MS. The amino terminus of the human $\mathrm{C} 5$ a receptor is required for high affinity $\mathrm{C} 5 \mathrm{a}$ binding and for receptor activation by C5a but not C5a analogs. J Biol Chem 1994;269:14446-14450. [PubMed: 8182049]

44. DiScipio RG, Daffern PJ, Jagels MA, Broide DH, Sriramarao P. A comparison of C3a and C5amediated stable adhesion of rolling eosinophils in postcapillary venules and transendothelial migration in vitro and in vivo. J Immunol 1999;162:1127-1136. [PubMed: 9916743]

45. Drouin SM, Corry DB, Hollman TJ, Kildsgaard J, Wetsel RA. Absence of the complement anaphylatoxin $\mathrm{C} 3$ a receptor suppresses $\mathrm{Th} 2$ effector functions in a murine model of pulmonary allergy. J Immunol 2002;169:5926-5933. [PubMed: 12421977]

46. Drouin SM, Corry DB, Kildsgaard J, Wetsel RA. Cutting edge: the absence of C3 demonstrates a role for complement in Th2 effector functions in a murine model of pulmonary allergy. $\mathrm{J}$ Immunol 2001;167:4141-4145. [PubMed: 11591733]

47. Drouin SM, Sinha M, Sfyroera G, Lambris JD, Wetsel RA. A protective role for the fifth complement component (c5) in allergic airway disease. Am J Respir Crit Care Med 2006;173:852-857. [PubMed: 16439722]

48. Ehrengruber MU, Geiser T, Deranleau DA. Activation of human neutrophils by C3a and C5A. Comparison of the effects on shape changes, chemotaxis, secretion, and respiratory burst. FEBS Lett 1994;346:181-184. [PubMed: 8013630]

49. el Lati SG, Dahinden CA, Church MK. Complement peptides C3a- and C5a-induced mediator release from dissociated human skin mast cells. J Invest Dermatol 1994;102:803-806. [PubMed: 7513741]

50. El-Naggar AK, Van-Epps DE, Williams RCJ. Human-B and T-lymphocyte locomotion in response to casein, C5a, and f-met-leu-phe. Cell Immunol 1980;56:365-373. [PubMed: 6970626]

51. Elsner J, Oppermann M, Czech W, Dobos G, Schopf E, Norgauer J, Kapp A. C3a activates reactive oxygen radical species production and intracellular calcium transients in human eosinophils. Eur J Immunol 1994a;24:518-522. [PubMed: 8125125]

52. Elsner J, Oppermann M, Czech W, Kapp A. C3a activates the respiratory burst in human polymorphonuclear neutrophilic leukocytes via pertussis toxin-sensitive G-proteins. Blood 1994b; 83:3324-3331. [PubMed: 8193368]

53. Ember, JA.; Jagels, MA.; Hugli, TE. Characterization of complement anaphylatoxins and their biological responses. In: Volanakis, JE.; Frank, MM., editors. The human complement system in health and disease. Marcel Dekker Inc.; New York: 1998. p. 241-284.

54. Farkas I, Baranyi L, Liposits ZS, Yamamoto T, Okada H. Complement C5a anaphylatoxin fragment causes apoptosis in TGW neuroblastoma cells. Neuroscience 1998;86:903-911. [PubMed: 9692726] 
55. Farkas I, Takahashi M, Fukuda A, Yamamoto N, Akatsu H, Baranyi L, Tateyama H, Yamamoto T, Okada N, Okada H. Complement C5a receptor-mediated signaling may be involved in neurodegeneration in Alzheimer's disease. J Immunol 2003;170:5764-5771. [PubMed: 12759460]

56. Farzan M, Schnitzler CE, Vasilieva N, Leung D, Kuhn J, Gerard C, Gerard NP, Choe H. Sulfated tyrosines contribute to the formation of the C5a docking site of the human C5a anaphylatoxin receptor. J Exp Med 2001;193:1059-1066. [PubMed: 11342590]

57. Fayyazi A, Sandau R, Duong LQ, Gotze O, Radzun HJ, Schweyer S, Soruri A, Zwirner J. C5a receptor and interleukin- 6 are expressed in tissue macrophages and stimulated keratinocytes but not in pulmonary and intestinal epithelial cells. Am J Pathol 1999;154:495-501. [PubMed: 10027407]

58. Fayyazi A, Scheel O, Werfel T, Schweyer S, Oppermann M, otze O, Radzun HJ, Zwirner J. The C5a receptor is expressed in normal renal proximal tubular but not in normal pulmonary or hepatic epithelial cells. Immunology 2000;99:38-45. [PubMed: 10651939]

59. Fearon DT, Locksley RM. The instructive role of innate immunity in the acquired immune response. Science 1996;272:50-53. [PubMed: 8600536]

60. Fernandez HN, Hugli TE. Partial characterization of human C5a anaphylatoxin. I. Chemical description of the carbohydrate and polypeptide prtions of human C5a. J Immunol 1976;117:16881694. [PubMed: 1002996]

61. Fischer WH, Hugli TE. Regulation of B cell functions by C3a and C3a(desArg): suppression of TNFalpha, IL-6, and the polyclonal immune response. J Immunol 1997;159:4279-4286. [PubMed: 9379023]

62. Fischer WH, Jagels MA, Hugli TE. Regulation of IL-6 synthesis in human peripheral blood mononuclear cells by C3a and C3a(desArg). J Immunol 1999;162:453-459. [PubMed: 9886419]

63. Flaherty P, Radhakrishnan ML, Dinh T, Rebres RA, Roach TI, Jordan MI, Arkin AP. A dual receptor crosstalk model of G-protein-coupled signal transduction. PLoS Comput Biol 2008;4:e1000185. [PubMed: 18818727]

64. Flierl MA, Rittirsch D, Chen AJ, Nadeau BA, Day DE, Sarma JV, Huber-Lang MS, Ward PA. The complement anaphylatoxin C5a induces apoptosis in adrenomedullary cells during experimental sepsis. PLoS ONE 2008;3:e2560. [PubMed: 18648551]

65. Fonseca MI, Zhou J, Botto M, Tenner AJ. Absence of C1q leads to less neuropathology in transgenic mouse models of Alzheimer's disease. J Neurosci 2004;24:6457-6465. [PubMed: 15269255]

66. Fregonese L, Swan FJ, van Schadewijk A, Dolhnikoff M, Santos MA, Daha MR, Stolk J, Tschernig T, Sterk PJ, Hiemstra PS, Rabe KF, Mauad T. Expression of the anaphylatoxin receptors C3aR and C5aR is increased in fatal asthma. J Allergy Clin Immunol 2005;115:1148-1154. [PubMed: 15940127]

67. Fukuoka Y, Hugli TE. Demonstration of a specific C3a receptor on guinea pig platelets. J Immunol 1988;140:3496-3501. [PubMed: 3283237]

68. Gao H, Neff TA, Guo RF, Speyer CL, Sarma JV, Tomlins S, Man Y, Riedemann NC, Hoesel LM, Younkin E, Zetoune FS, Ward PA. Evidence for a functional role of the second C5a receptor C5L2. FASEB J 2005;19:1003-1005. [PubMed: 15784721]

69. Gao J, Choe H, Bota D, Wright PL, Gerard C, Gerard NP. Sulfation of tyrosine 174 in the human C3a receptor is essential for binding of C3a anaphylatoxin. J Biol Chem 2003;278:37902-37908. [PubMed: 12871936]

70. Gasque P, Singhrao SK, Neal JW, Gotze O, Morgan BP. Expression of the receptor for complement C5a (CD88) is up-regulated on reactive astrocytes, microglia, and endothelial cells in the inflamed human central nervous system. Am J Pathol 1997;150:31-41. [PubMed: 9006319]

71. Gasque P, Singhrao SK, Neal JW, Wang P, Sayah S, Fontaine M, Morgan BP. The receptor for complement anaphylatoxin $\mathrm{C} 3 \mathrm{a}$ is expressed by myeloid cells and nonmyeloid cells in inflamed human central nervous system: analysis in multiple sclerosis and bacterial meningitis. J Immunol 1998;160:3543-3554. [PubMed: 9531317]

72. Gavrilyuk V, Kalinin S, Hilbush BS, Middlecamp A, McGuire S, Pelligrino D, Weinberg G, Feinstein DL. Identification of complement 5a-like receptor (C5L2) from astrocytes: characterization of antiinflammatory properties. J Neurochem 2005;92:1140-1149. [PubMed: 15715664]

73. Gerard NP, Gerard C. The chemotactic receptor for human C5a anaphylatoxin. Nature 1991;349:614617. [PubMed: 1847994] 
74. Gerard NP, Hodges MK, Drazen JM, Weller PF, Gerard C. Characterization of a receptor for C5a anaphylatoxin on human eosinophils. J Biol Chem 1989;264:1760-1766. [PubMed: 2912983]

75. Gerard NP, Lu B, Liu P, Craig S, Fujiwara Y, Okinaga S, Gerard C. An anti-inflammatory function for the complement anaphylatoxin C5a-binding protein, C5L2. J Biol Chem 2005;280:39677-39680. [PubMed: 16204243]

76. Gerber BO, Meng EC, Dotsch V, Baranski TJ, Bourne HR. An Activation Switch in the Ligand Binding Pocket of the C5a Receptor. J Biol Chem 2000;276:3394-3400. [PubMed: 11062244]

77. Geva A, Lassere TB, Lichtarge O, Pollitt SK, Baranski TJ. Genetic mapping of the human C5a receptor identification of transmembrane amino acids critical for receptor function. J Biol Chem 2000;275:35393-35401. [PubMed: 10952985]

78. Glovsky MM, Hugli TE, Ishizaka T, Lichtenstein LM, Erickson BW. Anaphylatoxin-induced histamine release with human leukocytes: studies of $\mathrm{C} 3$ a leukocyte binding and histamine release. $\mathrm{J}$ Clin Invest 1979;64:804-811. [PubMed: 89118]

79. Godau J, Heller T, Hawlisch H, Trappe M, Howells E, Best J, Zwirner J, Verbeek JS, Hogarth PM, Gerard C, Van Rooijen N, Klos A, Gessner JE, Köhl J. C5a initiates the inflammatory cascade in immune complex peritonitis. J Immunol 2004;173:3437-3445. [PubMed: 15322209]

80. Grammas P, Ovase R. Inflammatory factors are elevated in brain microvessels in Alzheimer's disease. Neurobiol Aging 2001;22:837-842. [PubMed: 11754990]

81. Gueler F, Rong S, Gwinner W, Mengel M, Brocker V, Schon S, Greten TF, Hawlisch H, Polakowski T, Schnatbaum K, Menne J, Haller H, Shushakova N. Complement 5a receptor inhibition improves renal allograft survival. J Am Soc Nephrol 2008;19:2302-2312. [PubMed: 18753257]

82. Guo RF, Huber-Lang M, Wang X, Sarma V, Padgaonkar VA, Craig RA, Riedemann NC, McClintock SD, Hlaing T, Shi MM, Ward PA. Protective effects of anti-C5a in sepsis-induced thymocyte apoptosis. J Clin Invest 2000;106:1271-1280. [PubMed: 11086028]

83. Guo RF, Ward PA. Role of c5a in inflammatory responses. Annu Rev Immunol 2005;23:821-852. [PubMed: 15771587]

84. Gutzmer R, Lisewski M, Zwirner J, Mommert S, Diesel C, Wittmann M, Kapp A, Werfel T. Human monocyte-derived dendritic cells are chemoattracted to $\mathrm{C} 3$ a after upregulation of the $\mathrm{C} 3$ a receptor with interferons. Immunology 2004;111:435-443. [PubMed: 15056381]

85. Hack CE, Nuijens JH, Felt-Bersma RJ, Schreuder WO, Eerenberg-Belmer AJ, Paardekooper J, Bronsveld W, Thijs LG. Elevated plasma levels of the anaphylatoxins C3a and C4a are associated with a fatal outcome in sepsis. Am J Med 1989;86:20-26. [PubMed: 2783358]

86. Hageman GS, Anderson DH, Johnson LV, Hancox LS, Taiber AJ, Hardisty LI, Hageman JL, Stockman HA, Borchardt JD, Gehrs KM, Smith RJ, Silvestri G, Russell SR, Klaver CC, Barbazetto I, Chang S, Yannuzzi LA, Barile GR, Merriam JC, Smith RT, Olsh AK, Bergeron J, Zernant J, Merriam JE, Gold B, Dean M, Allikmets R. A common haplotype in the complement regulatory gene factor $\mathrm{H}$ (HF1/CFH) predisposes individuals to age-related macular degeneration. Proc Natl Acad Sci U S A 2005;102:7227-7232. [PubMed: 15870199]

87. Hajishengallis G, Wang M, Liang S, Shakhatreh MA, James D, Nishiyama S, Yoshimura F, Demuth DR. Subversion of innate immunity by periodontopathic bacteria via exploitation of complement receptor-3. Adv Exp Med Biol 2008;632:203-219. [PubMed: 19025124]

88. Hartmann K, Henz BM, Kruger-Krasagakes S, Köhl J, Burger R, Guhl S, Haase I, Lippert U, Zuberbier T. C3a and C5a stimulate chemotaxis of human mast cells. Blood 1997;89:2863-2870. [PubMed: 9108406]

89. Hawlisch H, Belkaid Y, Baelder R, Hildeman D, Gerard C, Köhl J. C5a negatively regulates Tolllike receptor 4-induced immune responses. Immunity 2005;22:415-426. [PubMed: 15845447]

90. Hawlisch H, Köhl J. Complement and Toll-like receptors: key regulators of adaptive immune responses. Mol Immunol 2006;43:13-21. [PubMed: 16019071]

91. Hebert LE, Scherr PA, Bienias JL, Bennett DA, Evans DA. Alzheimer disease in the US population: prevalence estimates using the 2000 census. Arch Neurol 2003;60:1119-1122. [PubMed: 12925369]

92. Heeger PS, Lalli PN, Lin F, Valujskikh A, Liu J, Muqim N, Xu Y, Medof ME. Decay-accelerating factor modulates induction of T cell immunity. J Exp Med 2005;201:1523-1530. [PubMed: 15883171] 
93. Heese K, Hock C, Otten U. Inflammatory signals induce neurotrophin expression in human microglial cells. J Neurochem 1998;70:699-707. [PubMed: 9453564]

94. Heller T, Gessner JE, Schmidt RE, Klos A, Bautsch W, Köhl J. Cutting edge: Fc receptor type I for $\mathrm{IgG}$ on macrophages and complement mediate the inflammatory response in immune complex peritonitis. J Immunol 1999a;162:5657-5661. [PubMed: 10229794]

95. Heller T, Hennecke M, Baumann U, Gessner JE, zu Vilsendorf AM, Baensch M, Boulay F, Kola A, Klos A, Bautsch W, Köhl J. Selection of a C5a receptor antagonist from phage libraries attenuating the inflammatory response in immune complex disease and ischemia/reperfusion injury. J Immunol 1999b;163:985-994. [PubMed: 10395696]

96. Hillebrandt S, Wasmuth HE, Weiskirchen R, Hellerbrand C, Keppeler H, Werth A, Schirin-Sokhan R, Wilkens G, Geier A, Lorenzen J, Köhl J, Gressner AM, Matern S, Lammert F. Complement factor 5 is a quantitative trait gene that modifies liver fibrogenesis in mice and humans. Nat Genet 2005;37:835-843. [PubMed: 15995705]

97. Hopken UE, Lu B, Gerard NP, Gerard C. The C5a chemoattractant receptor mediates mucosal defence to infection. Nature 1996;383:86-89. [PubMed: 8779720]

98. Hsu MH, Ember JA, Wang M, Prossnitz ER, Hugli TE, Ye RD. Cloning and functional characterization of the mouse C3a anaphylatoxin receptor gene. Immunogenetics 1997;47:64-72. [PubMed: 9382922]

99. Huber-Lang M, Sarma JV, Rittirsch D, Schreiber H, Weiss M, Flierl M, Younkin E, Schneider M, Suger-Wiedeck H, Gebhard F, McClintock SD, Neff T, Zetoune F, Bruckner U, Guo RF, Monk PN, Ward PA. Changes in the novel orphan, C5a receptor (C5L2), during experimental sepsis and sepsis in humans. J Immunol 2005;174:1104-1110. [PubMed: 15634936]

100. Huber-Lang M, Sarma JV, Zetoune FS, Rittirsch D, Neff TA, McGuire SR, Lambris JD, Warner RL, Flierl MA, Hoesel LM, Gebhard F, Younger JG, Drouin SM, Wetsel RA, Ward PA. Generation of C5a in the absence of C3: a new complement activation pathway. Nat Med 2006;12:682-687. [PubMed: 16715088]

101. Huber-Lang M, Sarma VJ, Lu KT, McGuire SR, Padgaonkar VA, Guo RF, Younkin EM, Kunkel RG, Ding J, Erickson R, Curnutte JT, Ward PA. Role of C5a in Multiorgan Failure During Sepsis. J Immunol 2001;166:1193-1199. [PubMed: 11145701]

102. Huber-Lang M, Younkin EM, Sarma JV, Riedemann N, McGuire SR, Lu KT, Kunkel R, Younger JG, Zetoune FS, Ward PA. Generation of C5a by phagocytic cells. Am J Pathol 2002a;161:18491859. [PubMed: 12414531]

103. Huber-Lang MS, Riedeman NC, Sarma JV, Younkin EM, McGuire SR, Laudes IJ, Lu KT, Guo RF, Neff TA, Padgaonkar VA, Lambris JD, Spruce L, Mastellos D, Zetoune FS, Ward PA. Protection of innate immunity by C5aR antagonist in septic mice. FASEB J 2002b;16:1567-1574. [PubMed: 12374779]

104. Humayun S, Gohar M, Volkening K, Moisse K, Leystra-Lantz C, Mepham J, McLean J, Strong MJ. The complement factor C5a receptor is upregulated in NFL-/- mouse motor neurons. $\mathrm{J}$ Neuroimmunol. 2009

105. Humbles AA, Lu B, Nilsson CA, Lilly C, Israel E, Fujiwara Y, Gerard NP, Gerard C. A role for the C3a anaphylatoxin receptor in the effector phase of asthma. Nature 2000;406:998-1001. [PubMed: 10984054]

106. Ip WK, Takahashi K, Moore KJ, Stuart LM, Ezekowitz RA. Mannose-binding lectin enhances Tolllike receptors 2 and 6 signaling from the phagosome. J Exp Med 2008;205:169-181. [PubMed: 18180310]

107. Ischenko A, Sayah S, Patte C, Andreev S, Gasque P, Schouft MT, Vaudry H, Fontaine M. Expression of a functional anaphylatoxin C3a receptor by astrocytes. J Neurochem 1998;71:2487-2496. [PubMed: 9832147]

108. Jakobsdottir J, Conley YP, Weeks DE, Ferrell RE, Gorin MB. C2 and CFB genes in age-related maculopathy and joint action with CFH and LOC387715 genes. PLoS ONE 2008;3:e2199. [PubMed: 18493315]

109. Jana M, Palencia CA, Pahan K. Fibrillar amyloid-beta peptides activate microglia via TLR2: implications for Alzheimer's disease. J Immunol 2008;181:7254-7262. [PubMed: 18981147] 
110. Jauneau AC, Ischenko A, Chatagner A, Benard M, Chan P, Schouft MT, Patte C, Vaudry H, Fontaine $\mathrm{M}$. Interleukin $1 \mathrm{~b}$ and anaphylatoxins exert a synergistic effect on NGF expression by astrocytes. J Neuroinflammation 2006;3:8. [PubMed: 16594997]

111. Ji H, Ohmura K, Mahmood U, Lee DM, Hofhuis FM, Boackle SA, Takahashi K, Holers VM, Walport M, Gerard C, Ezekowitz A, Carroll MC, Brenner M, Weissleder R, Verbeek JS, Duchatelle V, Degott C, Benoist C, Mathis D. Arthritis critically dependent on innate immune system players. Immunity 2002;16:157-168. [PubMed: 11869678]

112. Jiang H, Burdick D, Glabe CG, Cotman CW, Tenner AJ. $\beta$-amyloid activates complement by binding to a specific region of the collagen-like domain of the C1q A chain. J Immunol 1994;152:50505059. [PubMed: 8176223]

113. Jiang H, Kuang Y, Wu Y, Smrcka A, Simon MI, Wu D. Pertussis toxin-sensitive activation of phospholipase C by the C5a and fMet-Leu-Phe receptors. J Biol Chem 1996;271:13430-13434. [PubMed: 8662841]

114. Johswich K, Klos A. C5L2--an anti-inflammatory molecule or a receptor for acylation stimulating protein (C3a-desArg)? Adv Exp Med Biol 2007;598:159-180. [PubMed: 17892211]

115. Johswich K, Martin M, Thalmann J, Rheinheimer C, Monk PN, Klos A. Ligand specificity of the anaphylatoxin C5L2 receptor and its regulation on myeloid and epithelial cell lines. J Biol Chem 2006;281:39088-39095. [PubMed: 17068344]

116. Jones SL, Knaus UG, Bokoch GM, Brown EJ. Two signaling mechanisms for activation of alphaM beta2 avidity in polymorphonuclear neutrophils. J Biol Chem 1998;273:10556-10566. [PubMed: 9553116]

117. Kajita T, Hugli TE. Evidence for in vivo degradation of C3a anaphylatoxin by mast cell chymase. I. Nonspecific activation of rat peritoneal mast cells by C3ades Arg. Am J Pathol 1991;138:13591369. [PubMed: 2053593]

118. Kalant D, Cain SA, Maslowska M, Sniderman AD, Cianflone K, Monk PN. The chemoattractant receptor-like protein C5L2 binds the C3a des-Arg77/acylation-stimulating protein. J Biol Chem 2003;278:11123-11129. [PubMed: 12540846]

119. Kalant D, Maclaren R, Cui W, Samanta R, Monk PN, Laporte SA, Cianflone K. C5L2 is a functional receptor for acylation-stimulating protein. J Biol Chem 2005;280:23936-23944. [PubMed: 15833747]

120. Karp CL, Grupe A, Schadt E, Ewart SL, Keane-Moore M, Cuomo PJ, Köhl J, Wahl L, Kuperman D, Germer S, Aud D, Peltz G, Wills-Karp M. Identification of complement factor 5 as a susceptibility locus for experimental allergic asthma. Nat Immunol 2000;1:221-226. [PubMed: 10973279]

121. Kemper C, Atkinson JP. T-cell regulation: with complements from innate immunity. Nat Rev Immunol 2007;7:9-18. [PubMed: 17170757]

122. Kemper C, Hourcade DE. Properdin: New roles in pattern recognition and target clearance. Mol Immunol 2008;45:4048-4056. [PubMed: 18692243]

123. Khodoun M, Strait R, Orekov T, Hogan S, Karasuyama H, Herbert DR, Köhl J, Finkelman FD. Peanuts can contribute to anaphylactic shock by activating complement. J Allergy Clin Immunol 2009;123:342-351. [PubMed: 19121857]

124. Klco JM, Lassere TB, Baranski TJ. C5a Receptor Oligomerization: I. disulfide trapping reveals oligomers and potential contact surfaces in a g protein-coupled receptor. J Biol Chem 2003;278:35345-35353. [PubMed: 12835319]

125. Klco JM, Nikiforovich GV, Baranski TJ. Genetic analysis of the first and third extracellular loops of the C5a receptor reveals an essential WXFG motif in the first loop. J Biol Chem 2006;281:1201012019. [PubMed: 16505476]

126. Klco JM, Wiegand CB, Narzinski K, Baranski TJ. Essential role for the second extracellular loop in C5a receptor activation. Nat Struct Mol Biol 2005;12:320-326. [PubMed: 15768031]

127. Klos A, Bank S, Gietz C, Bautsch W, Köhl J, Burg M, Kretzschmar T. C3a receptor on dibutyrylcAMP-differentiated U937 cells and human neutrophils: the human C3a receptor characterized by functional responses and 125I-C3a binding. Biochemistry 1992;31:11274-11282. [PubMed: 1332754] 
128. Köhl J. Anaphylatoxins and infectious and non-infectious inflammatory diseases. Mol Immunol 2001;38:175-187. [PubMed: 11532279]

129. Köhl J. Drug evaluation: the C5a receptor antagonist PMX-53. Curr Opin Mol Ther 2006a;8:529538.

130. Köhl J. The role of complement in danger sensing and transmission. Immunol Res 2006b;34:157176.

131. Köhl J, Baelder R, Lewkowich IP, Pandey MK, Hawlisch H, Wang L, Best J, Herman NS, Sproles AA, Zwirner J, Whitsett JA, Gerard C, Sfyroera G, Lambris JD, Wills-Karp M. A regulatory role for the C5a anaphylatoxin in type 2 immunity in asthma. J Clin Invest 2006;116:783-796. [PubMed: 16511606]

132. Kolakowski LF Jr, Lu B, Gerard C, Gerard NP. Probing the "message:address" sites for chemoattractant binding to the $\mathrm{C} 5$ a receptor Mutagenesis of hydrophilic and proline residues within the transmembrane segments. J Biol Chem 1995;270:18077-18082. [PubMed: 7629117]

133. Konrad S, Ali SR, Wiege K, Syed SN, Engling L, Piekorz RP, Hirsch E, Nurnberg B, Schmidt RE, Gessner JE. Phosphoinositide 3-kinases gamma and delta, linkers of coordinate C5a receptorFcgamma receptor activation and immune complex-induced inflammation 99. J Biol Chem 2008;283:33296-33303. [PubMed: 18786920]

134. Konteatis ZD, Siciliano SJ, Van R G, Molineaux CJ, Pandya S, Fischer P, Rosen H, Mumford RA, Springer MS. Development of C5a receptor antagonists Differential loss of functional responses. J Immunol 1994;153:4200-4205. [PubMed: 7930622]

135. Kretzschmar T, Jeromin A, Gietz C, Bautsch W, Klos A, Köhl J, Rechkemmer G, Bitter Suermann D. Chronic myelogenous leukemia-derived basophilic granulocytes express a functional active receptor for the anaphylatoxin C3a. Eur J Immunol 1993;23:558-561. [PubMed: 7679650]

136. Krug N, Tschernig T, Erpenbeck VJ, Hohlfeld JM, Köhl J. Complement factors c3a and c5a are increased in bronchoalveolar lavage fluid after segmental allergen provocation in subjects with asthma. Am J Respir Crit Care Med 2001;164:1841-1843. [PubMed: 11734433]

137. Kumar V, Ali SR, Konrad S, Zwirner J, Verbeek JS, Schmidt RE, Gessner JE. Cell-derived anaphylatoxins as key mediators of antibody-dependent type II autoimmunity in mice. J Clin Invest 2006;116:512-520. [PubMed: 16453025]

138. la Sala A, Gadina M, Kelsall BL. G(i)-protein-dependent inhibition of IL-12 production is mediated by activation of the phosphatidylinositol 3-kinase-protein 3 kinase B/Akt pathway and JNK. J Immunol 2005;175:2994-2999. [PubMed: 16116186]

139. Lalli PN, Strainic MG, Lin F, Medof ME, Heeger PS. Decay Accelerating Factor Can Control T Cell Differentiation into IFN-\{gamma $\}$-Producing Effector Cells via Regulating Local C5aInduced IL-12 Production. J Immunol 2007;179:5793-5802. [PubMed: 17947652]

140. Lalli PN, Strainic MG, Yang M, Lin F, Medof ME, Heeger PS. Locally produced C5a binds to T cell-expressed $\mathrm{C} 5 \mathrm{aR}$ to enhance effector T-cell expansion by limiting antigen-induced apoptosis. Blood 2008;112:1759-1766. [PubMed: 18567839]153

141. Langkabel P, Zwirner J, Oppermann M. Ligand-induced phosphorylation of anaphylatoxin receptors C3aR and C5aR is mediated by "G protein-coupled receptor kinases. Eur J Immunol 1999;29:30353046. [PubMed: 10508278]

142. Laudes IJ, Chu JC, Huber-Lang M, Guo RF, Riedemann NC, Sarma JV, Mahdi F, Murphy HS, Speyer C, Lu KT, Lambris JD, Zetoune FS, Ward PA. Expression and function of C5a receptor in mouse microvascular endothelial cells. J Immunol 2002a;169:5962-5970. [PubMed: 12421982]

143. Laudes IJ, Chu JC, Sikranth S, Huber-Lang M, Guo RF, Riedemann N, Sarma JV, Schmaier AH, Ward PA. Anti-c5a ameliorates coagulation/fibrinolytic protein changes in a rat model of sepsis. Am J Pathol 2002b;160:1867-1875. [PubMed: 12000738]

144. Lee DK, George SR, Cheng R, Nguyen T, Liu Y, Brown M, Lynch KR, O'Dowd BF. Identification of four novel human $\mathrm{G}$ protein-coupled receptors expressed in the brain. Brain Res Mol Brain Res 2001;86:13-22. [PubMed: 11165367]

145. Lett-Brown MA, Leonard EJ. Histamine-induced inhibition of normal human basophil chemotaxis to C5a. J Immunol 1977;118:815-818. [PubMed: 845438] 
146. Lewis AG, Köhl G, Ma Q, Devarajan P, Köhl J. Pharmacological targeting of C5a receptors during organ preservation improves kidney graft survival. Clin Exp Immunol 2008;153:117-126. [PubMed: 18505432]

147. Lewkowich IP, Herman NS, Schleifer KW, Dance MP, Chen BL, Dienger KM, Sproles AA, Shah JS, Köhl J, Belkaid Y, Wills-Karp M. CD4+CD25+ T cells protect against experimentally induced asthma and alter pulmonary dendritic cell phenotype and function. J Exp Med 2005;202:1549-1561. [PubMed: 16314437]

148. Lewkowich IP, Lajoie S, Clark JR, Herman NS, Sproles AA, Wills-Karp M. Allergen uptake, activation, and IL-23 production by pulmonary myeloid DCs drives airway hyperresponsiveness in asthma-susceptible mice. PLoS ONE 2008;3:e3879. [PubMed: 19060952]

149. Li K, Anderson KJ, Peng Q, Noble A, Lu B, Kelly AP, Wang N, Sacks SH, Zhou W. Cyclic AMP plays a critical role in $\mathrm{C} 3 \mathrm{a}-$-receptor-mediated regulation of dendritic cells in antigen uptake and $\mathrm{T}$ cell stimulation. Blood 2008;112:5084-5094. [PubMed: 18812470]

150. Liese J, Schleicher U, Bogdan C. The innate immune response against Leishmania parasites. Immunobiology 2008;213:377-387. [PubMed: 18406382]

151. Locati M, Torre YM, Galliera E, Bonecchi R, Bodduluri H, Vago G, Vecchi A, Mantovani A. Silent chemoattractant receptors: D6 as a decoy and scavenger receptor for inflammatory CC chemokines. Cytokine Growth Factor Rev 2005;16:679-686. [PubMed: 15996892]

152. Loeffler DA, Camp DM, Bennett DA. Plaque complement activation and cognitive loss in Alzheimer's disease. J Neuroinflammation 2008;5:9. [PubMed: 18334032]

153. Lotz M, Ebert S, Esselmann H, Iliev AI, Prinz M, Wiazewicz N, Wiltfang J, Gerber J, Nau R. Amyloid beta peptide 1-40 enhances the action of Toll-like receptor-2 and -4 agonists but antagonizes Toll-like receptor-9-induced inflammation in primary mouse microglial cell cultures. J Neurochem 2005;94:289-298. [PubMed: 15998280]

154. Lue LF, Rydel R, Brigham EF, Yang LB, Hampel H, Murphy GM Jr, Brachova L, Yan SD, Walker DG, Shen Y, Rogers J. Inflammatory repertoire of Alzheimer's disease and nondemented elderly microglia in vitro. Glia 2001;35:72-79. [PubMed: 11424194]

155. Maller JB, Fagerness JA, Reynolds RC, Neale BM, Daly MJ, Seddon JM. Variation in complement factor 3 is associated with risk of age-related macular degeneration. Nat Genet 2007;39:1200-1201. [PubMed: 17767156]

156. Marigo I, Dolcetti L, Serafini P, Zanovello P, Bronte V. Tumor-induced tolerance and immune suppression by myeloid derived suppressor cells. Immunol Rev 2008;222:162-179. [PubMed: 18364001]

157. Markiewski MM, Deangelis RA, Benencia F, Ricklin-Lichtsteiner SK, Koutoulaki A, Gerard C, Coukos G, Lambris JD. Modulation of the antitumor immune response by complement. Nat Immunol 2008;9:1225-1235. [PubMed: 18820683]

158. Markiewski MM, Lambris JD. The role of complement in inflammatory diseases from behind the scenes into the spotlight. Am J Pathol 2007;171:715-727. [PubMed: 17640961]

159. Markiewski MM, Mastellos D, Tudoran R, Deangelis RA, Strey CW, Franchini S, Wetsel RA, Erdei A, Lambris JD. C3a and C3b activation products of the third component of complement (C3) are critical for normal liver recovery after toxic injury. J Immunol 2004;173:747-754. [PubMed: 15240660]

160. Marth T, Kelsall BL. Regulation of interleukin-12 by complement receptor 3 signaling. J Exp Med 1997;185:1987-1995. [PubMed: 9166428]

161. Martin U, Bock D, Arseniev L, Tornetta MA, Ames RS, Bautsch W, Köhl J, Ganser A, Klos A. The human $\mathrm{C} 3$ a receptor is expressed on neutrophils and monocytes, but not on B or T lymphocytes. $\mathrm{J}$ Exp Med 1997;186:199-207. [PubMed: 9221749]

162. Mastellos D, Papadimitriou JC, Franchini S, Tsonis PA, Lambris JD. A novel role of complement: mice deficient in the fifth component of complement (C5) exhibit impaired liver regeneration. J Immunol 2001;166:2479-2486. [PubMed: 11160308]

163. Matsumoto ML, Narzinski K, Kiser PD, Nikiforovich GV, Baranski TJ. A comprehensive structurefunction map of the intracellular surface of the human C5a receptor. I. Identification of critical residues. J Biol Chem 2007;282:3105-3121. [PubMed: 17135254] 
164. Matthews KW, Mueller-Ortiz SL, Wetsel RA. Carboxypeptidase N: a pleiotropic regulator of inflammation. Mol Immunol 2004;40:785-793. [PubMed: 14687935]

165. McGeer PL, McGeer EG. Inflammation and neurodegeneration in Parkinson's disease. Parkinsonism Relat Disord 2004;10:S3-S7. [PubMed: 15109580]

166. McKinley L, Kim J, Bolgos GL, Siddiqui J, Remick DG. Allergens induce enhanced bronchoconstriction and leukotriene production in C5 deficient mice. Respir Res 2006;7:129. [PubMed: 17044927]

167. Meda L, Baron P, Scarlato G. Glial activation in Alzheimer's disease: the role of Abeta and its associated proteins. Neurobiol Aging 2001;22:885-893. [PubMed: 11754995]

168. Mery L, Boulay F. Evidence that the extracellular N-terminal domain of C5aR contains amino-acid residues crucial for C5a binding. Eur J Haematol 1993;51:282-287. [PubMed: 8282089]

169. Miller AM, Stella N. Microglial cell migration stimulated by ATP and C5a involve distinct molecular mechanisms: Quantification of migration by a novel near-infrared method. Glia 2008;56

170. Monk PN, Partridge LJ. Characterization of a complement-fragment-C5a-stimulated calcium- influx mechanism in U937 monocytic cells. Biochem J 1993;295:679-684. [PubMed: 8240277]

171. Monk PN, Scola AM, Madala P, Fairlie DP. Function, structure and therapeutic potential of complement C5a receptors. Br J Pharmacol 2007;152:429-448. [PubMed: 17603557]

172. Monsinjon T, Gasque P, Chan P, Ischenko A, Brady JJ, Fontaine MC. Regulation by complement C3a and C5a anaphylatoxins of cytokine production in human umbilical vein endothelial cells. FASEB J 2003;17:1003-1014. [PubMed: 12773483]

173. Morelli A, Larregina A, Chuluyan I, Kolkowski E, Fainboim L. Expression and modulation of C5a receptor (CD88) on skin dendritic cells. Chemotactic effect of C5a on skin migratory dendritic cells. Immunology 1996;89:126-134. [PubMed: 8911150]

174. Mukherjee P, Pasinetti GM. The role of complement anaphylatoxin C5a in neurodegeneration: implications in Alzheimer's disease. J Neuroimmunol 2000;105:124-130. [PubMed: 10742554]

175. Mukherjee P, Pasinetti GM. Complement anaphylatoxin C5a neuroprotects through mitogenactivated protein kinase-dependent inhibition of caspase 3. J Neurochem 2001;77:43-49. [PubMed: 11279260]

176. Mullmann TJ, Siegel MI, Egan RW, Billah MM. Complement C5a activation of phospholipase D in human neutrophils. A major route to the production of phosphatidates and diglycerides. $\mathrm{J}$ Immunol 1990;144:1901-1908. [PubMed: 2307846]

177. Murakami Y, Imamichi T, Nagasawa S. Characterization of C3a anaphylatoxin receptor on guineapig macrophages. Immunology 1993;79:633-638. [PubMed: 8406589]

178. Nataf S, Davoust N, Ames RS, Barnum SR. Human T cells express the C5a receptor and are chemoattracted to C5a. J Immunol 1999a;162:4018-4023. [PubMed: 10201923]

179. Nataf S, Stahel PF, Davoust N, Barnum SR. Complement anaphylatoxin receptors on neurons: new tricks for old receptors? Trends Neurosci 1999b;22:397-402. [PubMed: 10441300]

180. Nettesheim DG, Edalji RP, Mollison KW, Greer J, Zuiderweg ER. Secondary structure of complement component C3a anaphylatoxin in solution as determined by NMR spectroscopy: differences between crystal and solution conformations. Proc Natl Acad Sci U S A 1988;85:50365040. [PubMed: 3260670]

181. Niederbichler AD, Hoesel LM, Westfall MV, Gao H, Ipaktchi KR, Sun L, Zetoune FS, Su GL, Arbabi S, Sarma JV, Wang SC, Hemmila MR, Ward PA. An essential role for complement C5a in the pathogenesis of septic cardiac dysfunction. J Exp Med 2006;203:53-61. [PubMed: 16380509]

182. Nimmerjahn F, Ravetch JV. Fcgamma receptors: old friends and new family members. Immunity 2006;24:19-28. [PubMed: 16413920]

183. Nordahl EA, Rydengard V, Nyberg P, Nitsche DP, Morgelin M, Malmsten M, Bjorck L, Schmidtchen A. Activation of the complement system generates antibacterial peptides. Proc Natl Acad Sci U S A 2004;101:16879-16884. [PubMed: 15550543]

184. Norgauer J, Dobos G, Kownatzki E, Dahinden C, Burger R, Kupper R, Gierschik P. Complement fragment $\mathrm{C} 3$ a stimulates $\mathrm{Ca} 2+$ influx in neutrophils via a pertussis-toxin-sensitive $\mathrm{G}$ protein. Eur $\mathrm{J}$ Biochem 1993;217:289-294. [PubMed: 8223566] 
185. O'Barr S, Cooper NR. The C5a complement activation peptide increases IL-1beta and IL-6 release from amyloid-beta primed human monocytes: implications for Alzheimer's disease. J Neuroimmunol 2000;109:87-94. [PubMed: 10996210]

186. O'Barr SA, Caguioa J, Gruol D, Perkins G, Ember JA, Hugli T, Cooper NR. Neuronal expression of a functional receptor for the C5a complement activation fragment. J Immunol 2001;166:41544162. [PubMed: 11238666]

187. Ohno M, Hirata T, Enomoto M, Araki T, Ishimaru H, Takahashi TA. A putative chemoattractant receptor, C5L2, is expressed in granulocyte and immature dendritic cells, but not in mature dendritic cells. Mol Immunol 2000;37:407-412. [PubMed: 11090875]

188. Okinaga S, Slattery D, Humbles A, Zsengeller Z, Morteau O, Kinrade MB, Brodbeck RM, Krause JE, Choe HR, Gerard NP, Gerard C. C5L2, a nonsignaling C5A binding protein. Biochemistry 2003;42:9406-9415. [PubMed: 12899627]

189. Osaka H, Mukherjee P, Aisen PS, Pasinetti GM. Complement-derived anaphylatoxin C5a protects against glutamate-mediated neurotoxicity. J Cell Biochem 1999;73:303-311. [PubMed: 10321830]

190. Ostrand-Rosenberg S. Cancer and complement. Nat Biotechnol 2008;26:1348-1349. [PubMed: 19060872]53

191. Ottonello L, Corcione A, Tortolina G, Airoldi I, Albesiano E, Favre A, D'Agostino R, Malavasi F, Pistoia V, Dallegri F. rC5a directs the in vitro migration of human memory and naive tonsillar B lymphocytes: implications for B cell trafficking in secondary lymphoid tissues. J Immunol 1999;162:6510-6517. [PubMed: 10352266]

192. Pasinetti GM. From epidemiology to therapeutic trials with anti-inflammatory drugs in Alzheimer's disease: the role of NSAIDs and cyclooxygenase in beta-amyloidosis and clinical dementia. J Alzheimers Dis 2002;4:435-445. [PubMed: 12446975]

193. Patel SN, Berghout J, Lovegrove FE, Ayi K, Conroy A, Serghides L, Min-oo G, Gowda DC, Sarma JV, Rittirsch D, Ward PA, Liles WC, Gros P, Kain KC. C5 deficiency and C5a or C5aR blockade protects against cerebral malaria. J Exp Med 2008;205:1133-1143. [PubMed: 18426986]

194. Peng Q, Li K, Anderson K, Farrar CA, Lu B, Smith RA, Sacks SH, Zhou W. Local production and activation of complement up-regulates the allostimulatory function of dendritic cells through C3aC3aR interaction. Blood 2008;111:2452-2461. [PubMed: 18056835]265

195. Peng Q, Li K, Patel H, Sacks SH, Zhou W. Dendritic cell synthesis of C3 is required for full T cell activation and development of a Th1 phenotype. J Immunol 2006;176:3330-3341. [PubMed: 16517700]

196. Peng T, Hao L, Madri JA, Su X, Elias JA, Stahl GL, Squinto S, Wang Y. Role of C5 in the development of airway inflammation, airway hyperresponsiveness, and ongoing airway response. J Clin Invest 2005;115:1590-1600. [PubMed: 15902311]

197. Perianayagam MC, Balakrishnan VS, King AJ, Pereira BJ, Jaber BL. C5a delays apoptosis of human neutrophils by a phosphatidylinositol 3-kinase-signaling pathway. Kidney Int 2002;61:456-463. [PubMed: 11849385]

198. Pratt JR, Basheer SA, Sacks SH. Local synthesis of complement component C3 regulates acute renal transplant rejection. Nat Med 2002;8:582-587. [PubMed: 12042808]

199. Rabiet MJ, Huet E, Boulay F. Complement component 5a receptor oligomerization and homologous receptor down-regulation. J Biol Chem 2008;283:31038-31046. [PubMed: 18772131]102

200. Raffetseder U, Roper D, Mery L, Gietz C, Klos A, Grotzinger J, Wollmer A, Boulay F, Köhl J, Bautsch W. Site-directed mutagenesis of conserved charged residues in the helical region of the human C5a receptor. Arg2O6 determines high- affinity binding sites of C5a receptor. Eur J Biochem 1996;235:82-90. [PubMed: 8631370]

201. Rahpeymai Y, Hietala MA, Wilhelmsson U, Fotheringham A, Davies I, Nilsson AK, Zwirner J, Wetsel RA, Gerard C, Pekny M, Pekna M. Complement: a novel factor in basal and ischemiainduced neurogenesis. Embo J 2006;25:1364-1374. [PubMed: 16498410]

202. Ratajczak J, Reca R, Kucia M, Majka M, Allendorf DJ, Baran JT, Janowska-Wieczorek A, Wetsel RA, Ross GD, Ratajczak MZ. Mobilization studies in mice deficient in either C3 or C3a receptor $(\mathrm{C} 3 \mathrm{aR})$ reveal a novel role for complement in retention of hematopoietic stem/progenitor cells in bone marrow. Blood 2004;103:2071-2078. [PubMed: 14604969] 
203. Ravetch JV, Lanier LL. Immune inhibitory receptors. Science 2000;290:84-89. [PubMed: 11021804]

204. Reca R, Mastellos D, Majka M, Marquez L, Ratajczak J, Franchini S, Glodek A, Honczarenko M, Spruce LA, Janowska-Wieczorek A, Lambris JD, Ratajczak MZ. Functional receptor for C3a anaphylatoxin is expressed by normal hematopoietic stem/progenitor cells, and C3a enhances their homing-related responses to SDF-1. Blood 2003;101:3784-3793. [PubMed: 12511407]

205. Ribas C, Penela P, Murga C, Salcedo A, Garcia-Hoz C, Jurado-Pueyo M, Aymerich I, Mayor F Jr. The $\mathrm{G}$ protein-coupled receptor kinase (GRK) interactome: role of GRKs in GPCR regulation and signaling. Biochim Biophys Acta 2007;1768:913-922. [PubMed: 17084806]

206. Rittirsch D, Flierl MA, Nadeau BA, Day DE, Huber-Lang M, Mackay CR, Zetoune FS, Gerard NP, Cianflone K, Köhl J, Gerard C, Sarma JV, Ward PA. Functional roles for C5a receptors in sepsis. Nat Med 2008;14:551-557. [PubMed: 18454156]

207. Rogers J, Cooper NR, Webster S, Schultz J, McGeer PL, Styren SD, Civin WH, Brachova L, Bradt B, Ward P, Lieberburg I. Complement activation by beta-amyloid in Alzheimer disease. Proc Natl Acad Sci 1992;89:10016-10020. [PubMed: 1438191]

208. Ryman D, Gao Y, Lamb BT. Genetic loci modulating amyloid-beta levels in a mouse model of Alzheimer's disease. Neurobiol Aging 2008;29:1190-1198. [PubMed: 17400334]

209. Samson M, Edinger AL, Stordeur P, Rucker J, Verhasselt V, Sharron M, Govaerts C, Mollereau C, Vassart G, Doms RW, Parmentier M. ChemR23, a putative chemoattractant receptor, is expressed in monocyte-derived dendritic cells and macrophages and is a coreceptor for SIV and some primary HIV-1 strains. Eur J Immunol 1998;28:1689-1700. [PubMed: 9603476]

210. Sayah S, Jauneau AC, Patte C, Tonon MC, Vaudry H, Fontaine M. Two different transduction pathways are activated by $\mathrm{C} 3 \mathrm{a}$ and $\mathrm{C} 5 \mathrm{a}$ anaphylatoxins on astrocytes. Brain Res Mol Brain Res 2003;112:53-60. [PubMed: 12670702]

211. Schraufstatter IU, Trieu K, Sikora L, Sriramarao P, DiScipio R. Complement c3a and c5a induce different signal transduction cascades in endothelial cells. J Immunol 2002;169:2102-2110. [PubMed: 12165538]

212. Scola AM, Higginbottom A, Partridge LJ, Reid RC, Woodruff T, Taylor SM, Fairlie DP, Monk PN. The role of the $\mathrm{N}$-terminal domain of the complement fragment receptor C5L2 in ligand binding. J Biol Chem 2007;282:3664-3671. [PubMed: 17158873]

213. Scola AM, Johswich KO, Morgan BP, Klos A, Monk PN. The human complement fragment receptor, C5L2, is a recycling decoy receptor 45. Mol Immunol 2009;46:1149-1162. [PubMed: 19100624]

214. Selberg O, Hecker H, Martin M, Klos A, Bautsch W, Köhl J. Discrimination of sepsis and systemic inflammatory response syndrome by determination of circulating plasma concentrations of procalcitonin, protein complement 3a, and interleukin-6. Crit Care Med 2000;28:2793-2798. [PubMed: 10966252]

215. Settmacher B, Bock D, Saad H, Gartner S, Rheinheimer C, Köhl J, Bautsch W, Klos A. Modulation of C3a activity: internalization of the human $\mathrm{C} 3 \mathrm{a}$ receptor and its inhibition by C5a. J Immunol 1999;162:7409-7416. [PubMed: 10358194]

216. Sewell DL, Nacewicz B, Liu F, Macvilay S, Erdei A, Lambris JD, Sandor M, Fabry Z. Complement C3 and C5 play critical roles in traumatic brain cryoinjury: blocking effects on neutrophil extravasation by C5a receptor antagonist. J Neuroimmunol 2004;155:55-63. [PubMed: 15342196]

217. Shaftel SS, Griffin WS, O'Banion MK. The role of interleukin-1 in neuroinflammation and Alzheimer disease: an evolving perspective. J Neuroinflammation 2008;5:7. [PubMed: 18302763]

218. Shushakova N, Skokowa J, Schulman J, Baumann U, Zwirner J, Schmidt RE, Gessner JE. C5a anaphylatoxin is a major regulator of activating versus inhibitory FcgammaRs in immune complexinduced lung disease. J Clin Invest 2002;110:1823-1830. [PubMed: 12488432]

219. Siciliano SJ, Rollins TE, DeMartino J, Konteatis Z, Malkowitz L, Van Riper G, Bondy S, Rosen H, Springer MS. Two-site binding of C5a by its receptor: an alternative binding paradigm for G proteincoupled receptors. Proc Natl Acad Sci U S A 1994;91:1214-1218. [PubMed: 8108389]

220. Siciliano SJ, Rollins TE, Springer MS. Interaction between the C5a receptor and Gi in both the membrane-bound and detergent-solubilized states. J Biol Chem 1990;265:19568-19574. [PubMed: 2123189] 
221. Singhrao SK, Neal JW, Morgan BP, Gasque P. Increased complement biosynthesis by microglia and complement activation on neurons in Huntington's disease. Exp Neurol 1999;159:362-376. [PubMed: 10506508]

222. Skokowa J, Ali SR, Felda O, Kumar V, Konrad S, Shushakova N, Schmidt RE, Piekorz RP, Nurnberg B, Spicher K, Birnbaumer L, Zwirner J, Claassens JW, Verbeek JS, Van Rooijen N, Köhl J, Gessner JE. Macrophages induce the inflammatory response in the pulmonary Arthus reaction through $\mathrm{G}$ alpha i2 activation that controls C5aR and Fc receptor cooperation. J Immunol 2005;174:30413050. [PubMed: 15728518]

223. Soruri A, Kim S, Kiafard Z, Zwirner J. Characterization of C5aR expression on murine myeloid and lymphoid cells by the use of a novel monoclonal antibody. Immunol Lett 2003;88:47-52. [PubMed: 12853161]

224. Spencer KL, Hauser MA, Olson LM, Schmidt S, Scott WK, Gallins P, Agarwal A, Postel EA, Pericak-Vance MA, Haines JL. Protective effect of complement factor B and complement component 2 variants in age-related macular degeneration. Hum Mol Genet 2007;16:1986-1992. [PubMed: 17576744]

225. Spencer KL, Olson LM, Anderson BM, Schnetz-Boutaud N, Scott WK, Gallins P, Agarwal A, Postel EA, Pericak-Vance MA, Haines JL. C3 R102G polymorphism increases risk of age-related macular degeneration. Hum Mol Genet 2008;17:1821-1824. [PubMed: 18325906]

226. Stove S, Welte T, Wagner TO, Kola A, Klos A, Bautsch W, Köhl J. Circulating complement proteins in patients with sepsis or systemic inflammatory response syndrome. Clin Diagn Lab Immunol 1996;3:175-183. [PubMed: 8991632]

227. Strainic MG, Liu J, Huang D, An F, Lalli PN, Muqim N, Shapiro VS, Dubyak GR, Heeger PS, Medof ME. Locally produced complement fragments C5a and C3a provide both costimulatory and survival signals to naive CD4+ T cells. Immunity 2008;28:425-435. [PubMed: 18328742]

228. Strey CW, Markiewski M, Mastellos D, Tudoran R, Spruce LA, Greenbaum LE, Lambris JD. The proinflammatory mediators C3a and C5a are essential for liver regeneration. J Exp Med 2003;198:913-923. [PubMed: 12975457]

229. Sylvestre DL, Ravetch JV. Fc receptors initiate the Arthus reaction: redefining the inflammatory cascade. Science 1994;265:1095-1098. [PubMed: 8066448]

230. Takafuji S, Tadokoro K, Ito K. Effects of interleukin (IL)-3 and IL-5 on human eosinophil degranulation induced by complement components C3a and C5a. Allergy 1996;51:563-568. [PubMed: 8874660]

231. Takai T. Roles of Fc receptors in autoimmunity. Nat Rev Immunol 2002;2:580-592. [PubMed: 12154377]

232. Tardif M, Brouchon L, Rabiet MJ, Boulay F. Direct binding of a fragment of the Wiskott-Aldrich syndrome protein to the $\mathrm{C}$-terminal end of the anaphylatoxin $\mathrm{C} 5 \mathrm{a}$ receptor. Biochem $\mathrm{J}$ 2003;372:453-463. [PubMed: 12600272]

233. Terry, RD.; Masliah, E.; Hansen, LA. The neuropathology of Alzheimer disease and the structural basis of its cognitive alteration. In: Terry, RD.; Katzman, R.; Bick, KL.; Sisodia, SS., editors. Alzheimer Disease. Lippincott Williams \& Wilkins; New York: 1999. p. 187-206.

234. Trcka J, Moroi Y, Clynes RA, Goldberg SM, Bergtold A, Perales MA, Ma M, Ferrone CR, Carroll MC, Ravetch JV, Houghton AN. Redundant and alternative roles for activating Fc receptors and complement in an antibody-dependent model of autoimmune vitiligo. Immunity 2002;16:861-868. [PubMed: 12121667]

235. Trojanowski JQ, Lee VM. Pathological tau: a loss of normal function or a gain in toxicity? Nat Neurosci 2005;8:1136-1137. [PubMed: 16127446]

236. Van Beek J, Nicole O, Ali C, Ischenko A, MacKenzie ET, Buisson A, Fontaine M. Complement anaphylatoxin $\mathrm{C} 3 \mathrm{a}$ is selectively protective against NMDA-induced neuronal cell death. NeuroReport 2001;12:289-293. [PubMed: 11209937]

237. Van-Epps DE, Chenoweth DE. Analysis of the binding of fluorescent C5a and C3a to human peripheral blood leukocytes. J Immunol 1984;132:2862-2867. [PubMed: 6373920]

238. Varagunam M, Yaqoob MM, Dohler B, Opelz G. C3 polymorphisms and allograft outcome in renal transplantation. N Engl J Med 2009;360:874-880. [PubMed: 19246358] 
239. Veerhuis R, Van Breemen MJ, Hoozemans JM, Morbin M, Ouladhadj J, Tagliavini F, Eikelenboom P. Amyloid beta plaque-associated proteins C1q and SAP enhance the Abeta(1-42)peptide-induced cytokine secretion by adult human microglia in vitro. Acta Neuropathol (Berl) 2003;105:135-144. [PubMed: 12536224]

240. Venkatesha RT, Berla TE, Zaidi AK, Ali H. Distinct regulation of C3a-induced MCP-1/CCL2 and RANTES/CCL5 production in human mast cells by extracellular signal regulated kinase and PI3 kinase. Mol Immunol 2005;42:581-587. [PubMed: 15607817]

241. Wang H, Bloom O, Zhang M, Vishnubhakat JM, Ombrellino M, Che J, Frazier A, Yang H, Ivanova S, Borovikova L, Manogue KR, Faist E, Abraham E, Andersson J, Andersson U, Molina PE, Abumrad NN, Sama A, Tracey KJ. HMG-1 as a late mediator of endotoxin lethality in mice. Science 1999;285:248-251. [PubMed: 10398600]

242. Ward PA. The dark side of C5a in sepsis. Nat Rev Immunol 2004;4:133-142. [PubMed: 15040586]

243. Ward PA. Role of the complement in experimental sepsis. J Leukoc Biol 2008a;83:467-470. [PubMed: 17875813]

244. Ward PA. Sepsis, apoptosis and complement. Biochem Pharmacol 2008b;76:1383-1388. [PubMed: 18848819]

245. Watson MD, Roher AE, Kim KS, Spiegel K, Emmerling MR. Complement interactions with amyloid- $\beta 1-42$ : a nidus for inflammation in AD brains. Amyloid: Int J Exp Clin Invest 1997;4:147156.

246. Weinberg PF, Matthay MA, Webster RO, Roskos KV, Goldstein IM, Murray JF. Biologically active products of complement and acute lung injury in patients with the sepsis syndrome. Am Rev Respir Dis 1984;130:791-796. [PubMed: 6497161]

247. Werfel T, Kirchhoff K, Wittmann M, Begemann G, Kapp A, Heidenreich F, Gotze O, Zwirner J. Activated human T lymphocytes express a functional C3a receptor. J Immunol 2000;165:6599_ 6605. [PubMed: 11086104]

248. Werfel T, Oppermann M, Begemann G, Gotze O, Zwirner J. C5a receptors are detectable on mast cells in normal human skin and in psoriatic plaques but not in weal and flare reactions or in uticaria pigmentosa by immunohistochemistry. Arch Dermatol Res 1997;289:83-86. [PubMed: 9049041]

249. Werfel T, Zwirner J, Oppermann M, Sieber A, Begemann G, Drommer W, Kapp A, Gotze O. CD88 antibodies specifically bind to C5aR on dermal CD117+ and CD14+ cells and react with a desmosomal antigen in human skin. J Immunol 1996;157:1729-1735. [PubMed: 8759762]

250. Wetsel RA. Expression of the complement C5a anaphylatoxin receptor (C5aR) on non-myeloid cells. Immunol Lett 1995;44:183-187. [PubMed: 7797249]

251. Wilken HC, Rogge S, Gotze O, Werfel T, Zwirner J. Specific detection by flow cytometry of histidine-tagged ligands bound to their receptors using a tag-specific monoclonal antibody. $\mathrm{J}$ Immunol Methods 1999;226:139-145. [PubMed: 10410979]

252. Wills-Karp M. Interleukin-13 in asthma pathogenesis. Immunol Rev 2004;202:175-190. [PubMed: 15546393]

253. Wingrove JA, DiScipio RG, Chen Z, Potempa J, Travis J, Hugli TE. Activation of complement components $\mathrm{C} 3$ and $\mathrm{C} 5$ by a cysteine proteinase (gingipain-1) from Porphyromonas (Bacteroides) gingivalis. J Biol Chem 1992;267:18902-18907. [PubMed: 1527018]

254. Woodruff TM, Costantini KJ, Crane JW, Atkin JD, Monk PN, Taylor SM, Noakes PG. The complement factor C5a contributes to pathology in a rat model of amyotrophic lateral sclerosis. $\mathrm{J}$ Immunol 2008;181:8727-8734. [PubMed: 19050293]

255. Woodruff TM, Crane JW, Proctor LM, Buller KM, Shek AB, de V K, Pollitt S, Williams HM, Shiels IA, Monk PN, Taylor SM. Therapeutic activity of C5a receptor antagonists in a rat model of neurodegeneration. FASEB J 2006;20:1407-1417. [PubMed: 16816116]

256. Yao J, Harvath L, Gilbert DL, Colton CA. Chemotaxis by a CNS macrophage, the microglia. J Neurosci Res 1990;27:36-42. [PubMed: 2254955]

257. Zhang X, Kimura Y, Fang C, Zhou L, Sfyroera G, Lambris JD, Wetsel RA, Miwa T, Song WC. Regulation of Toll-like receptor-mediated inflammatory response by complement in vivo. Blood 2007;110:228-236. [PubMed: 17363730] 
258. Zhang X, Lewkowich IP, Köhl G, Clark JR, Wills-Karp M, Köhl J. A protective role for C5a in the development of allergic asthma associated with altered levels of B7-H1 and B7-DC on plasmacytoid dendritic cells. J Immunol 2009;182:5123-5130. [PubMed: 19342693]

259. Zhou J, Fonseca MI, Kayed R, Hernandez I, Webster SD, Yazan O, Cribbs DH, Glabe CG, Tenner AJ. Novel Abeta peptide immunogens modulate plaque pathology and inflammation in a murine model of Alzheimer's disease. J Neuroinflammation 2005;2:28. [PubMed: 16332263]

260. Zhou J, Fonseca MI, Pisalyaput K, Tenner AJ. Complement C3 and C4 expression in C1q sufficient and deficient mouse models of Alzheimer's disease. J Neurochem 2008;106:2080-2092. [PubMed: 18624920]

261. Zhou W, Patel H, Li K, Peng Q, Villiers MB, Sacks SH. Macrophages from C3-deficient mice have impaired potency to stimulate alloreactive T cells. Blood 2006;107:2461-2469. [PubMed: 16304047]

262. Zwirner J, Gotze O, Begemann G, Kapp A, Kirchhoff K, Werfel T. Evaluation of C3a receptor expression on human leucocytes by the use of novel monoclonal antibodies. Immunology 1999;97:166-172. [PubMed: 10447728]

263. Zwirner J, Gotze O, Sieber A, Kapp A, Begemann G, Zuberbier T, Werfel T. The human mast cell line HMC-1 binds and responds to C3a but not C3a(desArg). Scand J Immunol 1998a;47:19-24. [PubMed: 9467653]

264. Zwirner J, Werfel T, Wilken HC, Theile E, Gotze O. Anaphylatoxin C3a but not C3a(desArg) is a chemotaxin for the mouse macrophage cell line J774. Eur J Immunol 1998b;28:1570-1577. [PubMed: 9603462] 